\title{
Immobilization of Multi-Enzymes on Support Materials for Efficient Biocatalysis
}

\author{
Kongliang $\mathrm{Xu}^{1,2}$, Xuexiao Chen ${ }^{1,2}$, Renchao Zheng ${ }^{1,2 \star}$ and Yuguo Zheng ${ }^{1,2}$ \\ ${ }^{1}$ Key Laboratory of Bioorganic Synthesis of Zhejiang Province, College of Biotechnology and Bioengineering, Zhejiang \\ University of Technology, Hangzhou, China, ${ }^{2}$ Engineering Research Center of Bioconversion and Biopurification of Ministry of \\ Education, Zhejiang University of Technology, Hangzhou, China
}

Multi-enzyme biocatalysis is an important technology to produce many valuable chemicals in the industry. Different strategies for the construction of multi-enzyme systems have been reported. In particular, immobilization of multi-enzymes on the support materials has been proved to be one of the most efficient approaches, which can increase the enzymatic activity via substrate channeling and improve the stability and reusability of enzymes. A general overview of the characteristics of support materials and their corresponding attachment techniques used for multi-enzyme immobilization will be

OPEN ACCESS

Edited by: Wen-Yong Lou, South China University of Technology, China

Reviewed by: Gao-Wei Zheng, East China University of Science and Technology, China Rajni Hatti Kaul, Lund University, Sweden

${ }^{*}$ Correspondence: Renchao Zheng zhengrc@zjut.edu.cn

Specialty section:

This article was submitted to Bioprocess Engineering, a section of the journal Frontiers in Bioengineering and Biotechnology

Received: 22 March 2020 Accepted: 28 May 2020 Published: 30 June 2020

Citation:

Xu K, Chen $X$, Zheng $R$ and Zheng $Y$ (2020) Immobilization of Multi-Enzymes on Support Materials for Efficient Biocatalysis.

Front. Bioeng. Biotechnol. 8:660. doi: 10.3389/fbioe.2020.00660 provided here. This review will focus on the materials-based techniques for multi-enzyme immobilization, which aims to present the recent advances and future prospects in the area of multi-enzyme biocatalysis based on support immobilization.

\footnotetext{
Keywords: multi-enzyme immobilization, co-immobilization, support materials, immobilization technologies, biocatalysis
}

\section{INTRODUCTION}

In nature, almost all the cascade reactions in cell are catalyzed by the cooperation of various enzymes (Ricca et al., 2011; Sheldon and Woodley, 2018; Shi et al., 2018). For example, in the tricarboxylic acid (TCA) cycle, malate dehydrogenase (MD), citrate synthase (CS), and other enzymes regulate metabolic biosynthetic pathways by controlling the formation of intermediates (Barnes and Weitzman, 1986). Multi-enzyme biocatalysis is an important technology to produce many valuable chemicals in the industry (Britton et al., 2018; Huffman et al., 2019), which integrates several biocatalytic transformations, bridging the gap between single-enzyme catalysis, and whole-cell catalysis. Inspired from multi-enzyme reactions in vivo, researchers have attempted to construct functional multi-enzyme systems in vitro to produce desired chemicals (Mayer et al., 2001; Yang et al., 2019). Different strategies for the construction of multi-enzyme systems have been reported, including fusion of enzymes, enzyme-scaffold complexes and co-immobilization (Hwang and Lee, 2019).

Multi-enzyme immobilization is a technology that co-localizes multiple enzymes on suitable supports/carriers or combines enzymes using a linker without supports (Ren et al., 2019). Enzymes will be close to one another and the mass transfer limitation can be reduced through coimmobilization, which has been proved to increase the enzymatic activity via substrate channeling and improve the stability and reusability. As support materials can strongly affect the properties of enzymes, support selection has been considered as a hot topic in the field of enzyme immobilization. To date, various materials, such as graphene, carbon nanotubes (CNTs), metalorganic frameworks (MOFs), DNA nanostructures, polymers and silica, have been applied for 
multi-enzyme immobilization, which can efficiently protect enzymes from heavy metals, high temperatures, and other biologically challenging conditions (Sheldon and Woodley, 2018; Ren et al., 2019).

This review will provide a general overview of the characteristics of support materials and their corresponding attachment techniques used for multi-enzyme immobilization. Although some recent reviews have already summarized the co-immobilized techniques and their corresponding applications (Ansari and Husain, 2012; Shi et al., 2018; Hwang and Lee, 2019; Ren et al., 2019; Giannakopoulou et al., 2020), the review emphasizing on the supports is rare to date (Jia et al., 2014). This review will focus on the recent support materials for multi-enzyme immobilization (Figure 1), which aims to present the recent advances and future prospects in the area of multi-enzyme biocatalysis.

\section{MULTI-ENZYME IMMOBILIZATION TECHNOLOGIES}

There are three main techniques for multi-enzyme immobilization, including random co-immobilization, positional co-immobilization, and compartmentalization (Figure 2; Hwang and Lee, 2019). As the basic interaction between enzymes and supports is critical to understand the co-immobilized techniques, basic types of immobilization for enzymes will be discussed briefly before the introduction of the three techniques.

\section{Basic Types of Immobilization}

Methods for enzyme immobilization can be divided into three categories, including binding to a support, cross-linking, and encapsulation (entrapment) (Mosbach and Mattiasson, 1976; Sheldon and van Pelt, 2013). (a) Binding to a support refers to immobilize enzyme on suitable carriers by hydrophobic action, ion interaction, hydrogen bonding, specific affinity, covalent bonding, etc. (b) Cross-linking is a support-free immobilization method, which can bind enzymes together to form a network by a cross-linker. For example, the Schiff base bond can be formed between the double aldehyde group of glutaraldehyde (a typical cross-linking agent) and the amino group of the enzyme molecules, which can efficiently connect enzymes together. (c) Encapsulation means the entrapment of enzymes in a network or a hollow fiber or a microcapsule during material preparation.

\section{Random Co-immobilization}

Random co-immobilization is the simplest strategy to create a multi-enzyme system, in which multiple enzymes are randomly attached on the surface or embedded inside the carrier via adsorption, encapsulation, covalent attachment, cross-linking, etc. (Figure 2A). For instance, a tri-enzyme biocatalyst for one-pot starch hydrolysis was prepared by

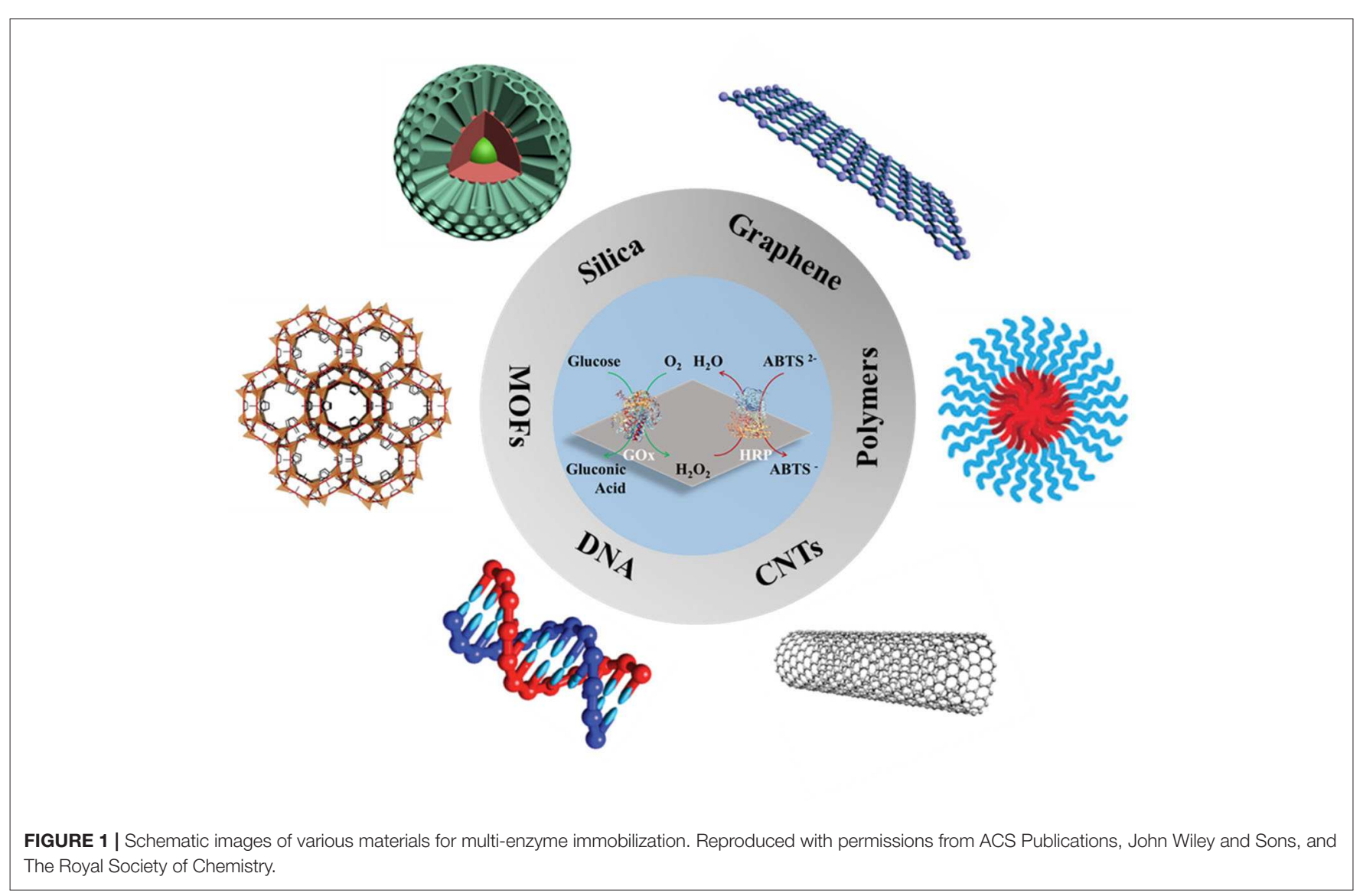



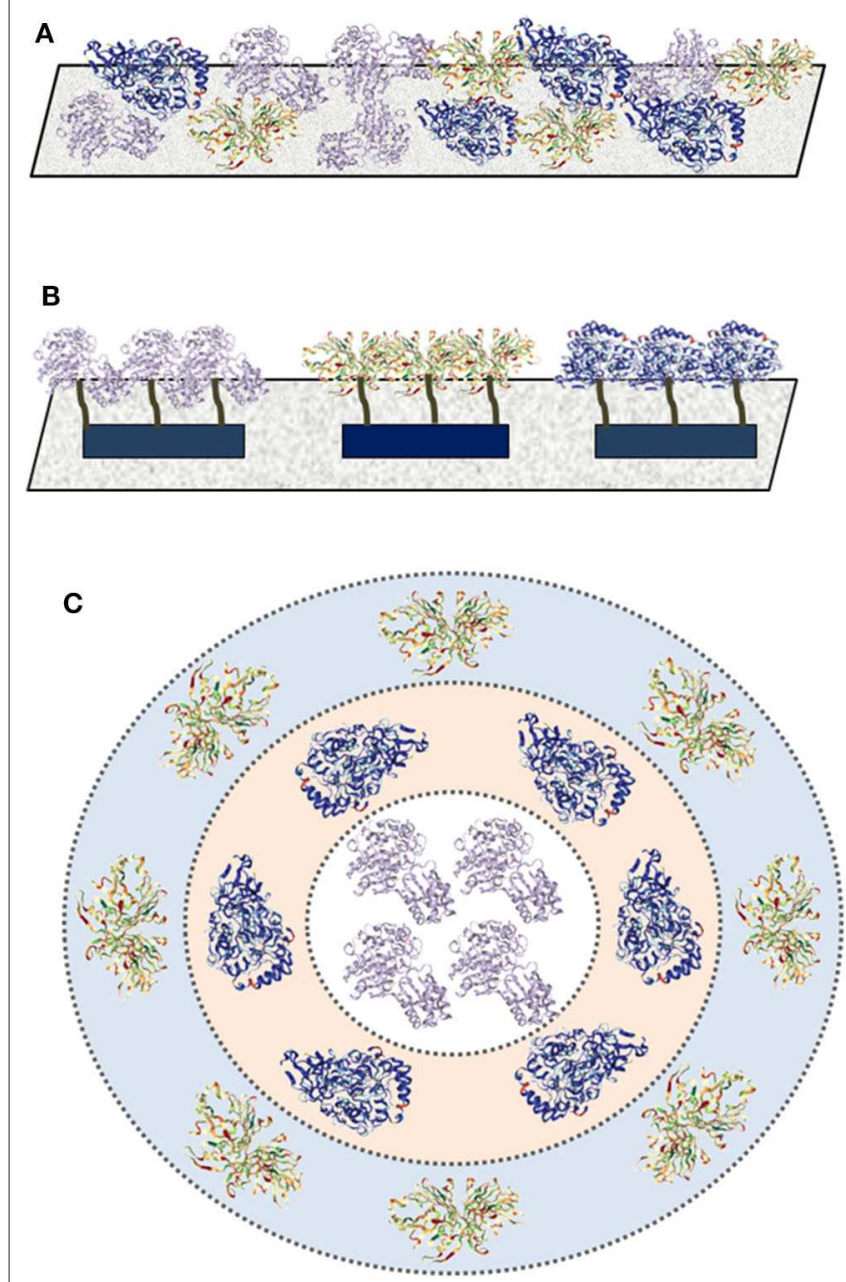

FIGURE 2 | Three techniques for multi-enzyme immobilization. (A) Random co-immobilization; (B) positional co-immobilization; and (C) compartmentalization.

ammonium sulfate aggregation and followed by glutaraldehydeassisted cross-linking, in which alpha amylase, glucoamylase, and pullulanase were randomly co-immobilized as crosslinked enzyme aggregates (Talekar et al., 2013). The resultant hydrolytic activity was well-maintained up to five cycles without obvious changes and the thermal stability was improved effectively.

\section{Positional Co-immobilization}

Positional co-immobilization has been proved to be an effective strategy for ordered multi-enzyme immobilization, which can control and improve the cascade enzymatic reaction rates via adjusting the immobilized sequence (Figure 2B). Polymers and DNA nanostructures are the common-used carriers for positional co-immobilization for their ability to control the relative positions of enzymes via specific interactions (see sections DNA Nanostructures and Polymers parts for more discussions).

\section{Compartmentalization}

As a mimic of natural enzyme organization in cellular environments, compartmentalization can spatially separate enzymes with different patterns and ratios (Figure 2C), which can protect enzymes against proteolysis, microbial degradation, or other harmful environments (Marguet et al., 2013). For example, Ge and Liu's group constructed a compartmentalized multi-enzyme system based on inorganic nanocrystal-protein complexes via a simple precipitation method (Li et al., 2014), which exhibited enhanced overall catalytic performance compared with free enzymes. Horseradish peroxidase (HRP) was first mixed with $\mathrm{CuSO}_{4}$ in water to form the HRP-incorporated complexes, then glucose oxidase (GOx) was adsorbed on the surface of the complexes by the coordination interaction between $\mathrm{Cu}^{2+}$ and amino acids of protein. Polymersome and colloidosome are the common materials for compartmentalized multi-enzyme immobilization (see sections Polymers and Silica parts for more discussions).

\section{SUPPORT MATERIALS FOR MULTI-ENZYME IMMOBILIZATION}

A great number of materials with different shapes/sizes, porous/non-porous structures, and binding functionalities have been designed as carriers for multi-enzyme immobilization and the following 6 main catalogs of support materials (Figure 1) will be overviewed.

\section{Graphene and Its Derivatives}

Graphene is a flat single-layer two-dimensional carbon atoms tightly packed into honeycomb lattice (Geim and Novoselov, 2007). Since its first isolation in 2004 (Novoselov et al., 2004), graphene has attracted tremendous scientific interests owing to its extraordinary properties, such as large theoretical specific surface area $\left(2,630 \mathrm{~m}^{2} \mathrm{~g}^{-1}\right)$, high intrinsic mobility $\left(200,000 \mathrm{~cm}^{2} \mathrm{v}^{-1} \mathrm{~s}^{-1}\right)$, high Young's modulus $(\sim 1.0 \mathrm{TPa})$ and high thermal conductivity $\left(\sim 5,000 \mathrm{~W} \mathrm{~m}^{-1} \mathrm{~K}^{-1}\right)$ (Zhu et al., 2010). There are four primary ways to produce graphene, including physical exfoliation, epitaxial growth, chemical vapor deposition, and oxidation-reduction method (Zhu et al., 2010). In particular, graphite oxidation-reduction method is commonly used at present due to its large-scale production. The process involves oxidizing graphite with a strong oxidant, followed by the exfoliation to graphene oxide (GO), and then uses a strong reducing agent to reduce GO to graphene. And the preparation of graphene oxide can be achieved by several methods, such as the Brodie, Staudenmaier, Hummers method, or some variation of these methods (Das et al., 2020).

Incredibly large specific surface area, along with the diversity of the functional groups on their surface [such as epoxy (C-O$\mathrm{C})$, hydroxyl $(-\mathrm{OH})$, carboxyl $(-\mathrm{COOH})$, and carbonyl groups $(\mathrm{C}-\mathrm{O})]$, makes graphene and its derivatives ideal substrates for enzyme/multi-enzyme immobilization in biological fields (Table 1 Park and Ruoff, 2009; Zhang et al., 2010; Wang et al., 2011; Ramakrishna et al., 2018). In 2014, Zhao et al. reported the 
TABLE 1 | Examples of multi-enzyme immobilization systems based on graphene and its derivatives.

\begin{tabular}{|c|c|c|c|c|}
\hline Materials & Model enzymes & Applications & $\begin{array}{l}\text { Types of } \\
\text { multi-immobilization }\end{array}$ & References \\
\hline $\begin{array}{l}\text { Chemically reduced } \\
\text { graphene oxide }\end{array}$ & GOx and glucoamylase & $\begin{array}{l}\text { Preparation of gluconic acid } \\
\text { from starch }\end{array}$ & Random co-immobilization & Zhao et al., 2014 \\
\hline $\begin{array}{l}\text { Reduced graphene } \\
\text { oxide-dendritic Pd } \\
\text { nanoparticles }\end{array}$ & $\begin{array}{l}\text { Cholesterol oxidase and } \\
\text { cholesterol esterase }\end{array}$ & Detection of cholesterol & Random co-immobilization & Dey and Raj, 2014 \\
\hline Graphene oxide & GOx and HRP & $\begin{array}{l}\text { Preparation of gluconic acid } \\
\text { from glucose }\end{array}$ & Random co-immobilization & Zore et al., 2015 \\
\hline $\begin{array}{l}\text { Chemically reduced } \\
\text { graphene oxide }\end{array}$ & GOx and HRP & $\begin{array}{l}\text { Preparation of gluconic acid } \\
\text { from glucose }\end{array}$ & Random co-immobilization & Mathesh et al., 2017 \\
\hline $\begin{array}{l}\text { Luminol functionalized } \\
\text { graphene oxide }\end{array}$ & GOx and HRP & Detection of glucose & Random co-immobilization & Li et al., 2018 \\
\hline $\begin{array}{l}\text { Hydroxyl and carboxyl } \\
\text { modified graphene oxide }\end{array}$ & Cellulase and GOx & $\begin{array}{l}\text { Preparation of gluconic acid } \\
\text { from carboxymethyl } \\
\text { cellulose }\end{array}$ & Random co-immobilization & Zhang et al., 2020 \\
\hline
\end{tabular}

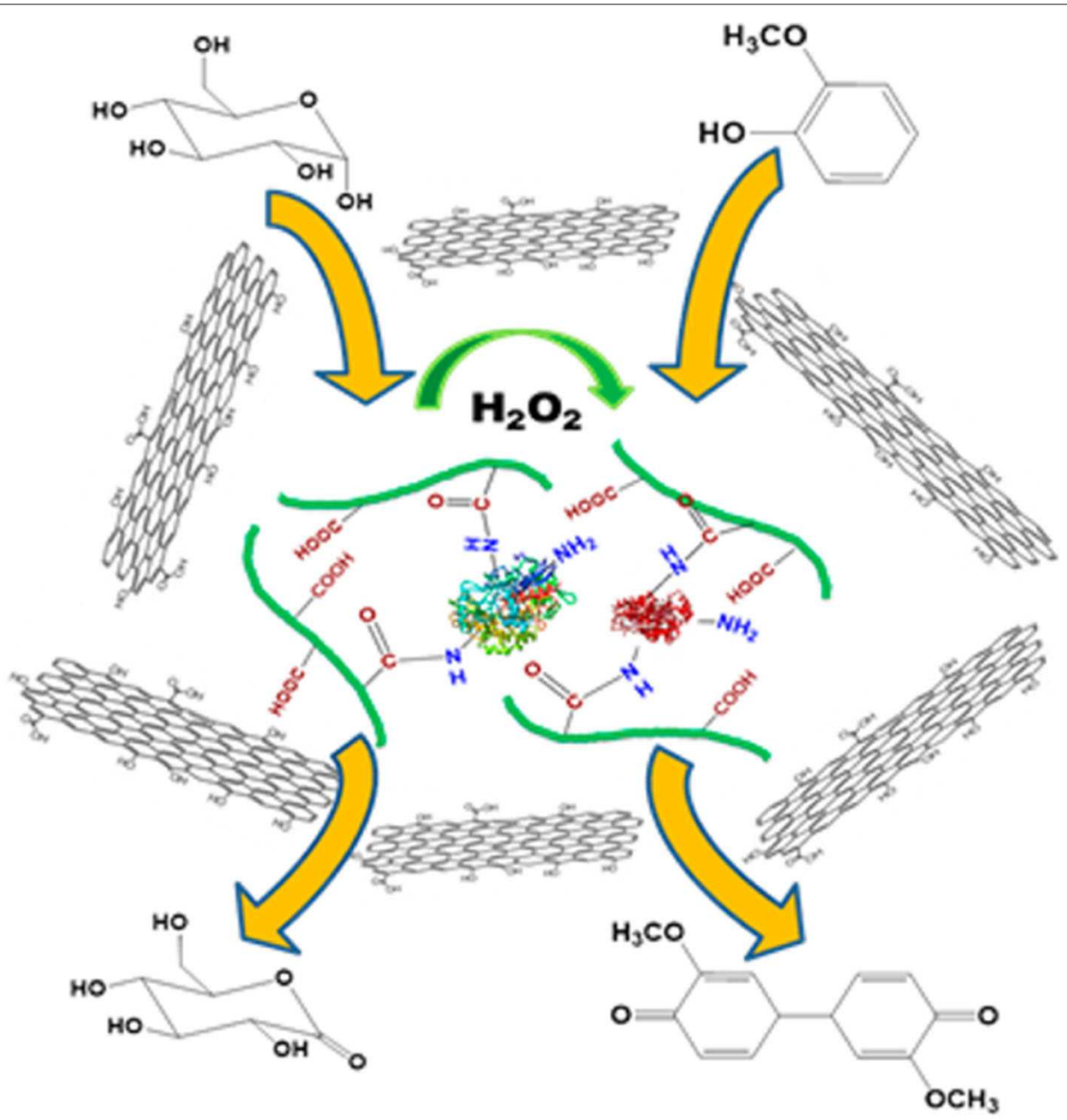

FIGURE 3 | Fabrication of bienzyme-polymer-GO quaternary hybrids for efficient biocatalysis (Zore et al., 2015). Reproduced with permission from ACS publications.

first case of co-immobilization of GOx and glucoamylase onto chemically reduced graphene oxide via non-covalent bonds for one-pot production of gluconic acid from starch (Zhao et al., 2014). The activity and reusability of the enzymes could be improved dramatically by controlling the extent of graphene oxide reduction. In order to keep the GO supported enzymes active at biologically challenging conditions, poly(acrylic acid) was used to covalently conjugate GOx and HRP together before 
TABLE 2 | Examples of multi-enzyme immobilization systems based on CNTs.

\begin{tabular}{|c|c|c|c|c|}
\hline Materials & Model enzymes & Applications & $\begin{array}{l}\text { Types of } \\
\text { multi-immobilization }\end{array}$ & References \\
\hline Amino-modified SWCNTs & $\begin{array}{l}\text { Glycerol dehydrogenase and } \\
\mathrm{NADH} \text { oxidase }\end{array}$ & $\begin{array}{l}\text { Preparation of } \\
\text { 4-hydroxy-2-butanone from } \\
\text { 1,3-butanediol }\end{array}$ & Random co-immobilization & Wang et al., 2012 \\
\hline MWCNTS & GOx and HRP & Detection of glucose & Random co-immobilization & Huang et al., 2013 \\
\hline MWCNTS & Glucoamylase and GOx & Detection of starch & Random co-immobilization & Lang et al., 2014 \\
\hline MWCNTS & $\begin{array}{l}\text { Salicylate hydroxylase and } \\
\text { tyrosinase }\end{array}$ & $\begin{array}{l}\text { Detection of methyl } \\
\text { salicylate }\end{array}$ & Random co-immobilization & Fang et al., 2016 \\
\hline CNT Columns & $\begin{array}{l}\text { Hydrogenase, } \mathrm{NAD}^{+} \text {reductase } \\
\text { and dehydrogenase }\end{array}$ & $\begin{array}{l}\text { Preparation of L-alanine/(S)- } \\
\text { 1-phenylethanol from } \\
\text { pyruvate/acetophenone }\end{array}$ & Random co-immobilization & Zor et al., 2017 \\
\hline
\end{tabular}

the immobilization of enzymes onto GO (Figure 3; Zore et al., 2015). The resultant bienzyme-polymer-GO quaternary hybrids functioned as active catalysts under extreme $\mathrm{pH}$ and high temperature conditions, and the stability of the enzymes was also improved in the presence of a chemical denaturant.

Later, Yang's group carried out a systematic investigation to understand the enzyme structural changes and conformations that could enhance activity and substrate channeling of GOsupported enzymes (Mathesh et al., 2017). It was observed that the hydrophobicity of graphene oxides and various enzyme architectures were important attributions for achieving high product conversion rates (GOx and HRP as model enzymes). Randomly immobilized enzymes resulted into extremely efficient substrate channeling with a transient time of close to $0 \mathrm{~s}$, owing to direct molecular channeling of the close to one another enzymes. Inspired from the previous works, a multienzyme system for one-pot production of gluconic acid from carboxymethyl cellulose was achieved by co-immobilization of cellulase and GOx on graphene oxide via covalent bonding (Zhang et al., 2020). Moreover (reduced), graphene oxide hybrids can also be used to fabricate multi-enzyme systems for sensitive biosensing (Dey and Raj, 2014; Li et al., 2018).

Graphene and its derivatives are rapidly becoming the most intensively studied carbon-based materials for multienzyme immobilization due to their large specific surface area and the diversity of the functional groups. Among graphene and its derivatives, graphene oxide and partially reduced graphene oxide, rather than pristine graphene (with little surface functionalization), are the common-used supports for multienzyme immobilization due to the abundant functional groups (Table 1). However, co-immobilized enzymes on water-dispersed graphene oxide are difficult to be separated (Chang et al., 2015), and the partially reduced graphene oxides with strong $\pi-\pi$ stacking are easily to aggregate with each other, resulting in the loss of surface functional groups. Moreover, the positions of different enzymes can hardly be precisely controlled on the surface of graphene and its derivatives. Thus, it still remains a long way for graphene and its derivatives to be utilized as support materials for multi-enzyme immobilization in the practical applications.

\section{Carbon Nanotubes (CNTs)}

CNTs are nanoscale circular tubes consisting of a hexagonal arrangement of hybridized carbon atoms, which are formed by a single or multi-layer graphene sheets coiled around the central axis at a certain rotation angle (Ebbesen, 1996). They can be divided into single-walled carbon nanotubes (SWCNTs) and multi-walled carbon nanotubes (MWCNTs). CNTs have received extensive attention due to their extraordinary properties, such as high specific surface area, large aspect ratios, remarkable mechanical strength and excellent chemical stability (Walcarius et al., 2013). There are three main ways to produce nanotubes, including the carbon arc, carbon vapor deposition, and laser ablation of graphite (Dai, 2002).

CNTs are attractive platforms for enzyme/multi-enzyme immobilization (Table 2), in which enzymes can be attached onto CNTs via physical adsorption or cross-linking (Ratautas et al., 2015). CNTs can protect enzymes from inactivation in harsh environments due to the suppression of the lateral interactions between adjacent adsorbed proteins (Asuri et al., 2006). $\mathrm{NAD}^{+}$dependent glycerol dehydrogenase and $\mathrm{NAD}^{+}$-regenerating NADH oxidase were co-immobilized on functionalized SWCNTs to achieve cofactor regeneration through the specific interaction between His-tagged enzymes and the modified SWCNTs (Wang et al., 2012). SWCNTs were modified by treating pristine SWCNTs with $\mathrm{HNO}_{3}$ and $\mathrm{H}_{2} \mathrm{SO}_{4}$ mixture to produce SWCNT$\mathrm{COOH}$, and activated with $\mathrm{N}$-hydroxysuccinimide/1-ethyl-3[3'-(dimethylamino) propyl] carbodiimide. Then $\mathrm{N}_{\alpha}, \mathrm{N}_{\alpha}$-bis (carboxymethyl)-L-lysine hydrate (ANTA)- $\mathrm{Co}^{2+}$ was attached to the surface of activated SWCNTs by carbodiimide cross-linking, resulting into SWCNT-ANTA-Co ${ }^{2+}$ complex (Wang et al., 2010, 2012). The resultant nanoscale biocatalysts were employed to produce 4-hydroxy-2-butanone $(4 \mathrm{H} 2 \mathrm{~B})$ by the oxidation of 1,3 butanediol. The multi-enzyme system was more stable and the yield of $4 \mathrm{H} 2 \mathrm{~B}$ was almost twice than that of the free enzymes under optimum conditions. For example, SWCNT-GlyDH could still preserve $\sim 90 \%$ of its initial activity after $30 \mathrm{~min}$ incubation at $60^{\circ} \mathrm{C}$ (with a half-life of $\sim 400 \mathrm{~min}$ ), whereas the activity of native GlyDH dropped sharply to $\sim 67 \%$ (with a half-life of $\sim 240 \mathrm{~min}$ ).

Similarly, to promote cofactor regeneration, a modular approach to $\mathrm{H}_{2}$-driven biocatalytic hydrogenation reactions in continuous flow was presented by Vincent's group (Zor 
et al., 2017). Hydrogenase, $\mathrm{NAD}^{+}$reductase and alanine dehydrogenase were co-immobilized on carbon nanotube columns, which can act selectively on pyruvate to generate L-alanine (Figure 4). At a low substrate concentration $(2 \mathrm{mM})$, $90 \%$ conversion was observed, equating to a total turnover number of $19,600 \mathrm{NADH}$ per $\mathrm{NAD}+$ reductase. When the pyruvate concentration was higher $(12.5 \mathrm{mM}), 40 \%$ conversion could be obtained, equating to a total turnover number of $>54,000 \mathrm{NADH}$ per NAD+ reductase. This work showed the possibility of biocatalytic hydrogenations in continuous flow using enzymes immobilized on a CNT-lined quartz column. Furthermore, enzymes co-immobilized on CNTs have also been widely used in electrochemical cascade enzymatic reactions for biosensing (Huang et al., 2013; Lang et al., 2014; Fang et al., 2016).

In recent years, CNTs have received growing attention for multi-enzyme immobilization (Table 2), due to their high specific surface area, large aspect ratios, excellent chemical stability, etc. By modifying various functional groups [such as carboxyl (-COOH), amino $\left(-\mathrm{NH}_{2}\right)$, amino-phenyl $\left(\mathrm{C}_{6} \mathrm{H}_{4} \mathrm{NH}_{2}\right)$, benzoic acid $\left(\mathrm{C}_{6} \mathrm{H}_{4} \mathrm{COOH}\right)$, and nitro-phenyl $\left.\left(\mathrm{C}_{6} \mathrm{H}_{4} \mathrm{NO}_{2}\right)\right]$ on the surface of CNTs, the catalytic performances of immobilized enzymes can be improved obviously (Gao and Kyratzis, 2008; Bi et al., 2009; Pang et al., 2010; Yu et al., 2010). Thus, the design of efficient modifiers and the corresponding modification method need to be further investigated for CNTs-based multienzyme immobilization.

\section{Metal-Organic Frameworks (MOFs)}

MOFs are porous network structures with tridimensional crystalline, which are constructed by linking metal ions or clusters and organic ligands via coordination bonds (Furukawa et al., 2013; Hu et al., 2018). Geometrical configuration of MOFs (such as linear, octahedron, and plane of conical) is determined by the metal coordination number (Burnett et al., 2012). Since the first preparation of MOFs by cobalt ions and trimesic acid in 1995, MOFs have attracted extensive explorations due to their broad application potentials (Yaghi et al., 1995). To date, solvothermal, microwave-assisted, electrochemical, mechanochemical, and sonochemical methods have been successfully applied for the synthesis of MOFs (Dey et al., 2014). The features of large specific surface area (typically ranging from 1,000 to $10,000 \mathrm{~m}^{2} / \mathrm{g}$ ), high porosity (typically ranging from 1 to $10 \mathrm{~nm}$ ) and adjustable structure indicate that MOFs are ideal supports for enzyme immobilization (Deng et al., 2012; Lian et al., 2017; Liang et al., 2020). In addition, MOFs with large surface-to-volume ratios and multiple enzymes binding sites have been considered as promising carriers for multi-enzyme immobilization (Table 3).

Ge's groups reported the first case of a multiple enzymeincorporated MOF via a one-step and facile synthesis procedure in 2015 (Wu et al., 2015). The multi-enzyme system was constructed by embedding GOx and HRP in zeolitic imidazolate framework (ZIF-8) via co-precipitation in aqueous solution at ambient conditions, which exhibited high sensitivity (limit of glucose detection is $0.5 \mathrm{mM}$ ), high selectivity (no obvious activity toward other interfering compounds including fructose, mannose, galactose, maltose, lactose, and albumin) and longterm storage stability $(\sim 80 \%$ retention of initial overall activity after 7 days). Later, the above in situ entrapment method was adopted to co-immobilize $\alpha$-amylase and glucoamylase in

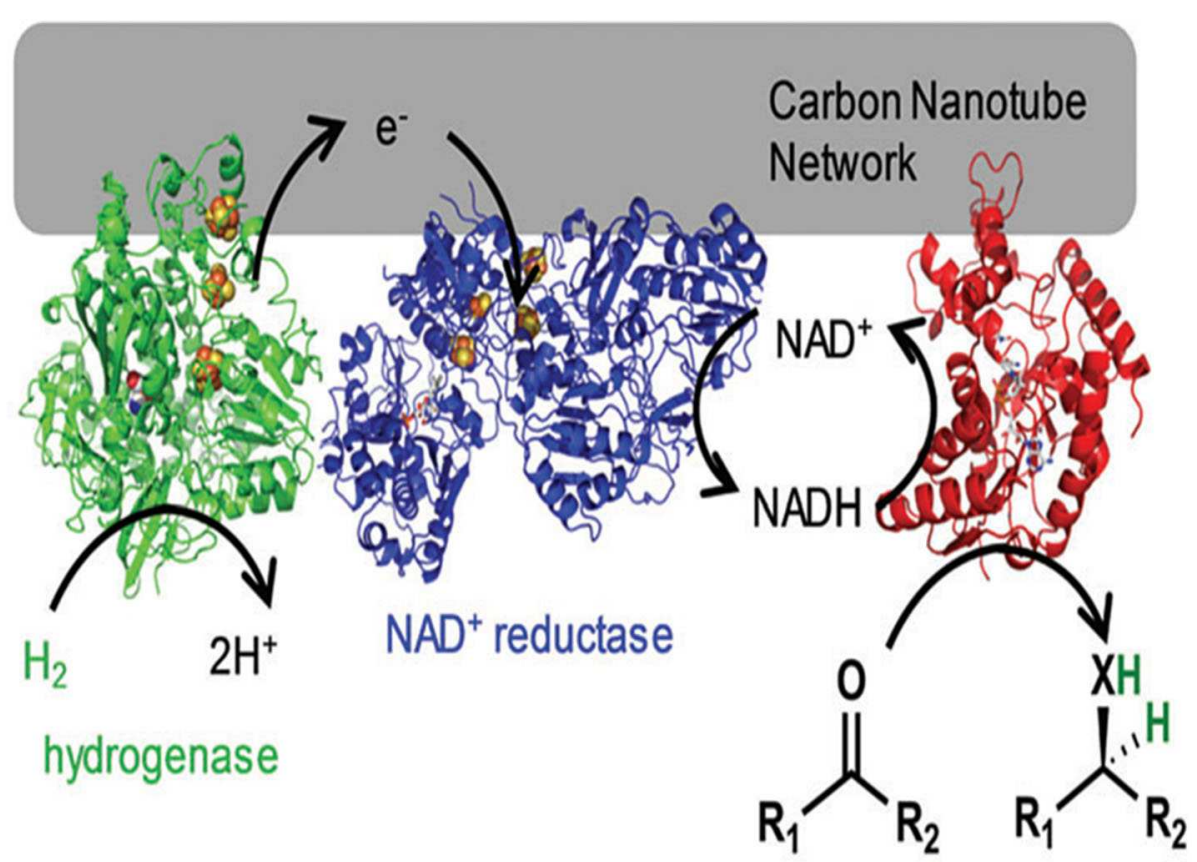

FIGURE 4 | A hydrogenase and $\mathrm{NAD}^{+}$reductase were co-immobilized on the carbon nanotube network for $\mathrm{H}_{2}$-driven $\mathrm{NADH}_{\text {generation }}$ (Zor et al., 2017). Reproduced with permission from The Royal Society of Chemistry. 
TABLE 3 | Examples of multi-enzyme immobilization systems based on MOFs.

\begin{tabular}{|c|c|c|c|c|}
\hline Materials & Model enzymes & Applications & $\begin{array}{l}\text { Types of } \\
\text { multi-immobilization }\end{array}$ & References \\
\hline ZIF-8 & GOx and HRP & Detection of glucose & Random co-immobilization & Wu et al., 2015 \\
\hline PCN-888 & GOx and HRP & $\begin{array}{l}\text { Preparation of gluconic acid } \\
\text { from glucose }\end{array}$ & Positional co-immobilization & Lian et al., 2016 \\
\hline $\begin{array}{l}\text { HKUST-1@ @ } \mathrm{Fe}_{3} \mathrm{O}_{4} \\
\text { nanoparticles }\end{array}$ & GOx and HRP & $\begin{array}{l}\text { Preparation of gluconic acid } \\
\text { from glucose }\end{array}$ & $\begin{array}{l}\text { Compartmentalization/Random } \\
\text { co-immobilization }\end{array}$ & Chen et al., 2017 \\
\hline ZIF-8 & Glucoamylase and $\alpha$-amylase & $\begin{array}{l}\text { Preparation of glucose from } \\
\text { starch }\end{array}$ & Random co-immobilization & $\begin{array}{l}\text { Salgaonkar et al., } \\
2018\end{array}$ \\
\hline PCN-333 & Cholesterol oxidase and HRP & Detection of cholesterol & Compartmentalization & Zhao et al., 2019 \\
\hline $\begin{array}{l}\text { Amine-functionalized } \\
\text { MIL-101(Cr) }\end{array}$ & $\begin{array}{l}\text { Carbonic anhydrase, formate } \\
\text { dehydrogenase and glutamate } \\
\text { dehydrogenase }\end{array}$ & $\begin{array}{l}\text { Preparation of formic acid } \\
\text { from } \mathrm{CO}_{2}\end{array}$ & Compartmentalization & Li et al., 2019 \\
\hline
\end{tabular}

ZIF-8 for one-pot starch hydrolysis by another research group (Salgaonkar et al., 2018). More recently, Ge's groups developed a coarse-grained, particle-based model to understand the origin of high efficiency in confined multi-enzyme catalysis. They found that the property of reaction intermediates was the key in determining the reaction kinetics (Cao et al., 2019).

To precisely control the distribution of GOx and HRP, Zhou's group rationally designed and synthesized a novel hierarchical mesoporous MOF PCN-888 with three types of cavity (Lian et al., 2016). The largest cavity $(6.2 \mathrm{~nm})$ and the intermediate cavity $(5.0 \mathrm{~nm})$ could only accommodate one molecule of GOx and HRP, repectively (Figure 5). The smallest cavity $(2.0 \mathrm{~nm})$ was left empty as a diffusion pathway for substrates and products, which had sufficient size for neither GOx nor HRP. The resultant multi-enzyme system exhibited high catalytic efficiency $\left(k_{\text {cat }}=\right.$ $2.411 \times 10^{4} \mathrm{~s}^{-1}, K_{\mathrm{m}}=9.67 \mathrm{mM}$, and $v_{\max }=1.96 \times 10^{-3} \mathrm{mM}$ $\mathrm{s}^{-1}$ ), good cycling performance (the activity remained almost the same within four catalytic cycles) as well as the protective effect of the immobilized enzymes against trypsin digestion. Similarly, cholesterol oxidase and HRP were co-immobilized in the mesoporous cages and the surface of MOF PCN-333(Al), which was used as a colorimetric biosensor for the detection of cholesterol (Zhao et al., 2019). Tan and Lv's group also have made the contribution in the area of MOFs (HKUST-1) for multienzyme immobilization (Chen et al., 2017; Li et al., 2019). They adopted a layer-by-layer self-assembly approach to achieve the sequential co-immobilization of multi-enzymes using MOFs in layered structure as the solid scaffold, which were used for the efficient biocatalytic conversion of adsorbed $\mathrm{CO}_{2}$ into formate.

Recently, MOFs have attracted considerable scientific interests as enzymes co-immobilized supports due to the large surfaceto-volume ratios and multiple enzyme binding sites, in which ZIF-8, PCN-888, HKUST-1, etc. are commonly used (Table 3). In spite of their advantages, the problems associated with the long-term water stability and potential leaching of toxic metal ions still need to be addressed to achieve the ideal multi-enzyme-MOF composites, which will be in line with the concept of sustainable green production. The future of MOFs for multi-enzyme immobilization lies in the simple, gentle, and eco-friendly synthesis method along with their potential industrial applications, in which the compatibility of the synthetic conditions with fragile enzymes should also be taken into consideration.

\section{DNA Nanostructures}

DNA nanotechnology has been demonstrated as a reliable way to fabricate complex biomolecular nanostructures due to the programmability of DNA hybridization (Pinheiro et al., 2011). For multi-enzyme immobilization, it is valuable to reduce the mass transfer resistance by controlling the relative positions and directions of different enzymes in a confined space. Thus, DNA nanotechnology has been utilized as an effective tool for the co-immobilization of various enzymes (Table 4), in which spatially addressable DNA nanostructures can facilitate the precise self-assembly of different enzymes to improve the substrate channeling.

DNA origami refers to the self-assembly of highly complex nanostructures by combining a long single strand of DNA with a series of short and engineered DNA fragments via the specific interaction between complementary base pairs (Rothemund, 2006). Immobilization of enzymes onto the DNA scaffold with precise positions is a promising approach for the selforganization of enzyme-DNA origami composite nanostructures. In 2009, Willner's group first explored the properties of the selfassembled DNA nanostructures as co-immobilized scaffolds for GOx and HRP (Wilner et al., 2009). The biocatalytic cascade reaction was activated by tethering GOx and HRP on twohexagon and four-hexagon DNA strips. The results showed that the biocatalytic rate operating on the two-hexagon templates was about 20 times faster than that on four-hexagon templates, owing to the high local concentration of the intermediate $\mathrm{H}_{2} \mathrm{O}_{2}$.

Yan's group systematically studied the activity of a GOx/HRP cascade spatially organized on DNA origami tiles as a function of interenzyme spacing and position (with the interenzyme distances varied from 10 to $65 \mathrm{~nm}$ ) (Fu et al., 2012). It was observed that closely spaced enzymes (10 $\mathrm{nm}$ apart) showed strongly enhanced activity and the activity dropped dramatically for enzymes as little as $20 \mathrm{~nm}$ apart. They also precisely mediated glucose-6-phosphate dehydrogenase (G6pDH) and malic dehydrogenase $(\mathrm{MDH})$ with an artificial swinging arm, 

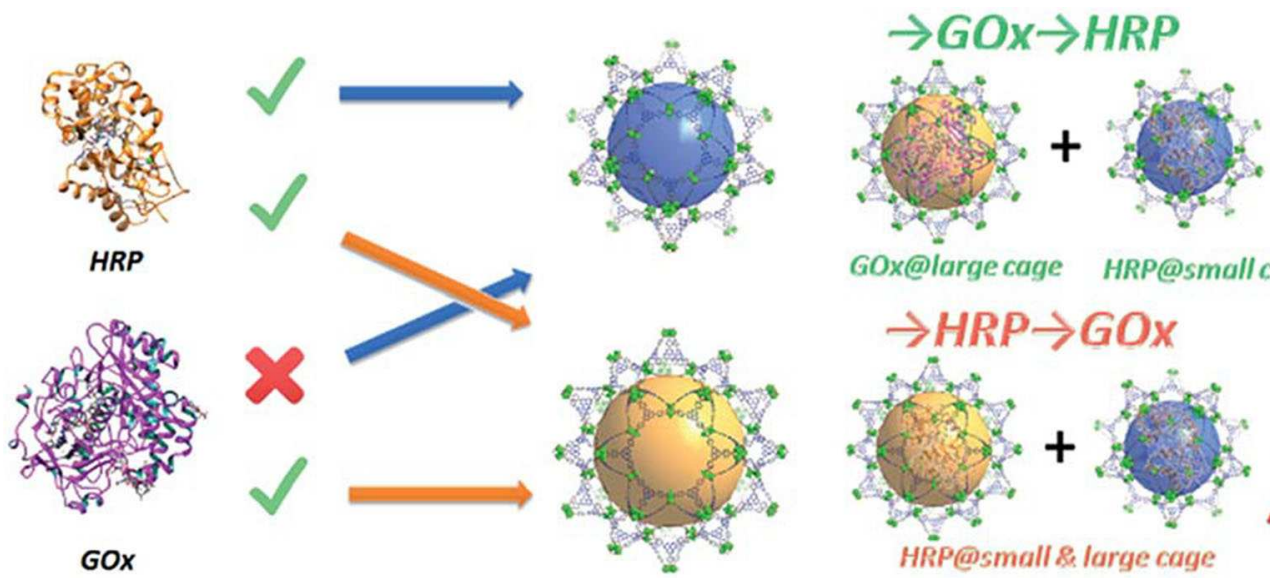

GOx@largecage HRP@small cage
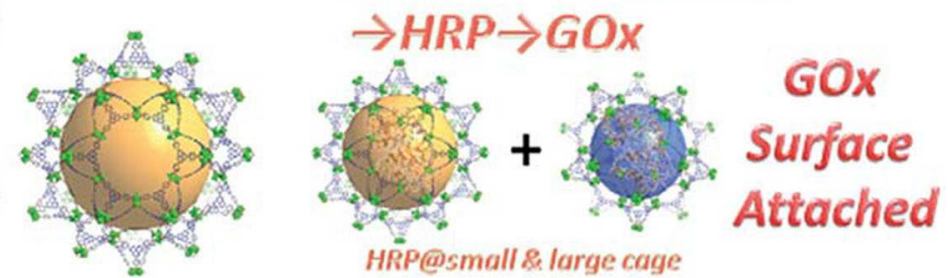

FIGURE 5 | Graphic representation of the stepwise encapsulation of GOx and HRP with different orders (Lian et al., 2016). Reproduced with permission from The Royal Society of Chemistry.

TABLE 4 | Examples of multi-enzyme immobilization systems based on DNA nanostructures.

\begin{tabular}{|c|c|c|c|c|}
\hline Materials & Model enzymes & Applications & $\begin{array}{l}\text { Types of } \\
\text { multi-immobilization }\end{array}$ & References \\
\hline $\begin{array}{l}\text { DNA origami (hexagon-like } \\
\text { strips) }\end{array}$ & GOx and HRP & $\begin{array}{l}\text { Preparation of gluconic acid } \\
\text { from glucose }\end{array}$ & Positional co-immobilization & Wilner et al., 2009 \\
\hline Rectangular DNA origami & GOx and HRP & $\begin{array}{l}\text { Preparation of gluconic acid } \\
\text { from glucose }\end{array}$ & Positional co-immobilization & Fu et al., 2012 \\
\hline DNA-inhibitor scaffold & Invertase, GOx and HRP & $\begin{array}{l}\text { Preparation of O-dianisidine } \\
\text { from sucrose and glucose }\end{array}$ & Positional co-immobilization & Liu et al., 2013 \\
\hline Rectangular DNA origami & GOx and HRP & $\begin{array}{l}\text { Preparation of gluconic acid } \\
\text { from glucose }\end{array}$ & Positional co-immobilization & Fu et al., 2013 \\
\hline DNA origami & G6pDH and $\mathrm{MDH}$ & $\begin{array}{l}\text { Preparation of malic acid } \\
\text { from oxaloacetic acid }\end{array}$ & Positional co-immobilization & Fu et al., 2014 \\
\hline DNA hybrid (polystyrene) & GOx and HRP & $\begin{array}{l}\text { Preparation of gluconic acid } \\
\text { from glucose }\end{array}$ & Positional co-immobilization & Jia et al., 2015 \\
\hline Rectangular DNA origami & $\begin{array}{l}\text { Xylose reductase and xylitol } \\
\text { dehydrogenase }\end{array}$ & $\begin{array}{l}\text { Preparation of xylulose from } \\
\text { D-xylose }\end{array}$ & Positional co-immobilization & Ngo et al., 2016 \\
\hline Triangle DNA origami & GOx and Catalase & $\begin{array}{l}\text { Preparation of gluconic acid } \\
\text { from glucose }\end{array}$ & Compartmentalization & Sun et al., 2017 \\
\hline $\begin{array}{l}\text { DNA hybrid (dopamine@ } \\
\text { magnetic nanoparticles) }\end{array}$ & GOx and HRP & $\begin{array}{l}\text { Preparation of gluconic acid } \\
\text { from glucose }\end{array}$ & Random co-immobilization & Yang et al., 2017 \\
\hline $\begin{array}{l}\text { DNA hybrid }\left(\mathrm{Fe}_{3} \mathrm{O}_{4} @ \mathrm{SiO}_{2}\right. \\
\text { nanoparticles) }\end{array}$ & GOx and HRP & Detection of target DNA & Random co-immobilization & Song et al., 2018 \\
\hline DNA nanotweezer & GOx and HRP & Detection of glucose & Positional co-immobilization & Kou et al., 2018 \\
\hline Rectangular DNA origami & $\begin{array}{l}\text { Glucose 6-phosphate } \\
\text { dehydrogenase and lactate } \\
\text { dehydrogenase }\end{array}$ & $\begin{array}{l}\text { Preparation of } \\
6 \text {-Phosphogluconic acid, } \\
\text { lactate from } \\
\text { glucose-6-phosphate, } \\
\text { pyruvate }\end{array}$ & Positional co-immobilization & Chen Y. et al., 2018 \\
\hline Triangle DNA origami & $\begin{array}{l}\text { Amylase, maltase and } \\
\text { glucokinase }\end{array}$ & $\begin{array}{l}\text { Preparation of } \\
\text { glucose-6-phosphate from } \\
\text { maltoheptaose }\end{array}$ & Positional co-immobilization & Klein et al., 2019 \\
\hline DNA Tetrahedron scaffold & GOx and HRP & Detection of glucose & Positional co-immobilization & Wang D. et al., 2019 \\
\hline
\end{tabular}

which showed that enzymatic activity was closely related to the number, position, and direction of the swinging arm relative to the enzymes (Fu et al., 2014). More recently, Yan's and
Yang's groups co-developed a synthetic light-driven substrate channeling system based on DNA origami (Figure 6), which could precisely regulate the enzyme cascade activity (Chen Y. 
et al., 2018). Glucose-6-phosphate dehydrogenase (G6pDH) and lactate dehydrogenase $(\mathrm{LDH})$ were served as the model cascade enzymes, and nicotinamide adenine dinucleotide $\left(\mathrm{NAD}^{+}\right)$was served as the cofactor, which were conjugated with a Holliday junction $(\mathrm{HJ})$ to form a swing arm between G6pDH and LDH on DNA origami. Under visible light (Vis) irradiation, azobenzenemodified arm of $\mathrm{HJ}$ (called $\mathrm{HJ}$-arm-AZO) hybridized with the azobenzene-modified anchor strand (called anchor-AZO), leading the swing arm far away from the enzyme cascade, which switched off its activity (left panel in Figure 6). When ultraviolet light (UV) was applied, the isomerization of azobenzene resulted in the dehybridization of $\mathrm{HJ}$-arm-AZO and anchor-AZO, and the swing arm was released to swing between the two enzymes, thus strongly enhancing the cascade activity (right panel in Figure 6).

Lu's group demonstrated a general design of robust enzyme nanocomplex by conjugating invertase, GOx, and HRP via the

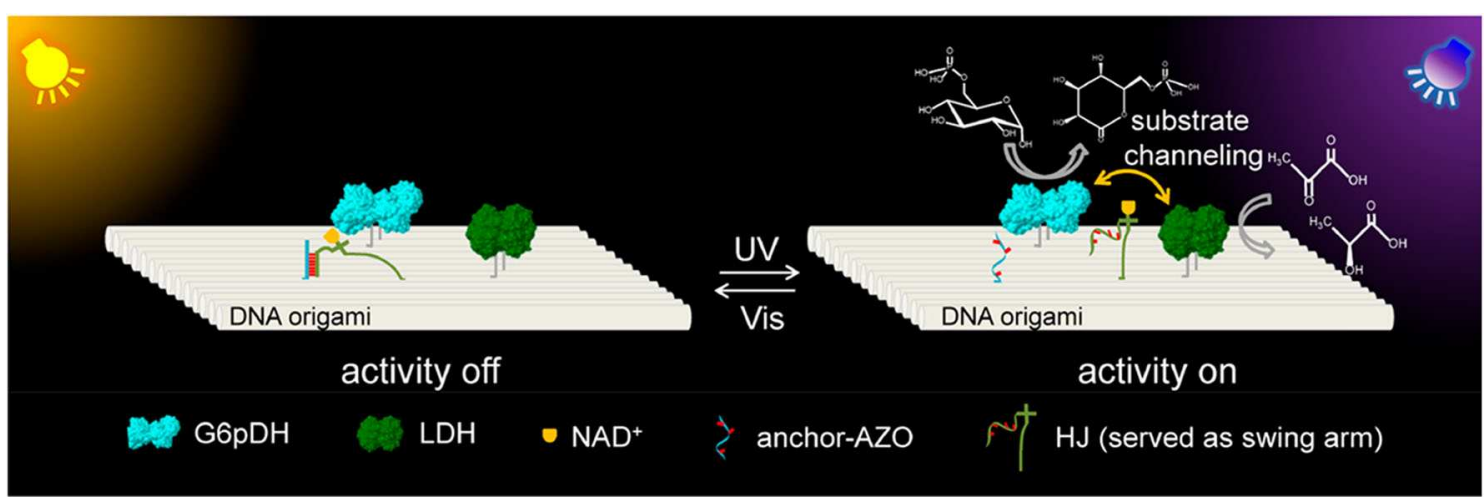

FIGURE 6 | G6pDH-LDH enzyme cascade and NAD+ - HJ swing arm assembly on DNA origami scaffold (Chen Y. et al., 2018). The swing arm was fixed to be far away from the two enzymes under Vis due to the hybridization of $\mathrm{HJ}$-arm-AZO and anchor-AZO, which turned off enzyme cascade activity. Under UV light, the swing arm was released to freely swing between both enzymes to switch on the enzyme cascade activity. Reproduced with permission from ACS publications.

TABLE 5 | Examples of multi-enzyme immobilization systems based on polymers.

\begin{tabular}{|c|c|c|c|c|}
\hline Materials & Model enzymes & Applications & $\begin{array}{l}\text { Types of } \\
\text { multi-immobilization }\end{array}$ & References \\
\hline Polystyrene nanoparticles & FDH, FaldDH, ADH and GDH & $\begin{array}{l}\text { Preparation of methanol } \\
\text { from } \mathrm{CO}_{2}\end{array}$ & Random co-immobilization & El-Zahab et al., 2008 \\
\hline Polydopamine microcapsule & $\begin{array}{l}\alpha \text {-amylase, } \beta \text {-amylase and } \\
\text { glucosidase }\end{array}$ & $\begin{array}{l}\text { Preparation of } \\
\text { isomaltooligosaccharide } \\
\text { from starch }\end{array}$ & Compartmentalization & Zhang et al., 2011 \\
\hline $\begin{array}{l}\text { Dendronized polymer } \\
(\text { de-PG1 } 2000)\end{array}$ & Superoxide dismutase and HRP & $\begin{array}{l}\text { Preparation of } \mathrm{ABTS}^{\bullet-}, \mathrm{O}_{2} \\
\text { from } \mathrm{ABTS}^{2-}, \mathrm{O}_{2}^{\bullet-}\end{array}$ & Random co-immobilization & Grotzky et al., 2012 \\
\hline Polyurethane hollow nanofiber & 3a-HSD, DP and NADH & $\begin{array}{l}\text { Preparation of 3-O-bile acid } \\
\text { from bile acids }\end{array}$ & Random co-immobilization & Ji et al., 2014 \\
\hline ABA polymersomes & GOx and HRP & $\begin{array}{l}\text { Preparation of } \\
\text { D-gluconolactone from } \\
\text { glucose }\end{array}$ & Compartmentalization & Siti et al., 2014 \\
\hline $\begin{array}{l}\text { Supramolecular-polymeric hybrid } \\
\text { hydrogel }\end{array}$ & GOx and HRP & $\begin{array}{l}\text { Preparation of gluconic acid, } \\
\text { phenazine-2,3-diamine from } \\
\text { glucose, } \\
\text { O-phenylenediamine }\end{array}$ & Random co-immobilization & Wei et al., 2016 \\
\hline PNIPAm-PEI & $\begin{array}{l}\text { Pyruvate kinase and L-lactic } \\
\text { dehydrogenase }\end{array}$ & $\begin{array}{l}\text { Preparation of lactate from } \\
\text { phosphoenol pyruvate }\end{array}$ & $\begin{array}{l}\text { Random co- } \\
\text { immobilization/compartmentalization }\end{array}$ & Dubey et al., 2016 \\
\hline $\begin{array}{l}\text { PMOXA-PDMS-PMOXA } \\
\text { Polymersomes }\end{array}$ & AGE, NAL and CSS & $\begin{array}{l}\text { Preparation of } \\
\text { CMP-Neu5Ac from GlcNAc, } \\
\text { pyruvate and CTP }\end{array}$ & Compartmentalization & Klermund et al., 2017 \\
\hline Polyglycidyl methacrylate sphere & GOx and catalase & $\begin{array}{l}\text { Preparation of gluconic acid } \\
\text { from glucose }\end{array}$ & Random co-immobilization & Liao et al., 2019 \\
\hline $\begin{array}{l}\text { LDPE-g-poly(PEGDA)/BG-g- } \\
\text { PAANa } \\
\text { film }\end{array}$ & $\beta$-glucosidase and cellulase & $\begin{array}{l}\text { Preparation of glucose from } \\
\text { cellulose }\end{array}$ & Compartmentalization & Wang Y. et al., 2019 \\
\hline
\end{tabular}


specific binding of DNA-inhibitor scaffold and multiple enzymes, followed by the encapsulation in a thin polymer shell (Liu et al., 2013). The enzyme nanocomplex showed improved efficiency and enhanced stability as well as complementary and synergic functions. The method was also applied for the design of an alcohol prophylactic and antidote by assembling alcohol oxidase $(\mathrm{AOx})$ and catalase on the DNA scaffold. Ngo et al. reported the fabrication of an artificial enzyme cascade based on the xylose metabolic pathway, in which xylose reductase and xylitol dehydrogenase were localized to specific positions on DNA origami with three rectangular cavities by DNA-binding protein adaptors (Ngo et al., 2016). In addition to triangle DNA origami, DNA tetrahedron scaffold were also designed and used for the site-specific co-immobilization of various enzymes (Sun et al., 2017; Klein et al., 2019; Wang D. et al., 2019).

DNA tweezer is a regenerated scaffold that interenzyme distance can be easily manipulated. When external triggers exist, such as light or metal ions, DNA tweezers could be achieved autonomous switchable motion with an addressable conformation change. A regenerated DNA tweezer was designed to regulate interenzyme spacing via "open-close-open" strategy for highly efficient enzyme cascade amplification (Kou et al., 2018), which can overcome the drawbacks of inflexible, time-consuming operation of DNA origami method. GOx and HRP were, respectively, modified as model enzymes with the arms of opened DNA tweezer, which can enhance the catalytic efficiency for sensitive target DNA analysis at a low detection limit down to $30 \mathrm{fM}$.

Apart from DNA origami structures and DNA tweezers, DNA hybrids have also been utilized for multi-enzyme immobilization (Jia et al., 2015; Yang et al., 2017; Song et al., 2018). For example, Yang's group fabricated a multi-enzyme system by co-immobilizing GOx and HRP on dopamine functionalized magnetic nanoparticles through DNA directed immobilization. The resultant multi-enzyme system exhibited precise enzyme ratio control, high catalytic efficiency, magnetic recyclability, and enhanced stability. The Michaelis constant $K_{\mathrm{m}}$ and specificity constant $\left(k_{\text {cat }} / K_{\mathrm{m}}\right)$ of the multi-enzyme system were $1.41 \mathrm{mM}$ and $5.02 \mathrm{~s}^{-1} \mathrm{mM}^{-1}$, respectively, which were approximately twice the corresponding values of the free enzymes.

Over the last few years, biocompatible DNA nanostructures with tight coding and paring between bases have received considerable attentions in the field of biotechnology. And DNAbased materials have been proved as a reliable platform for the fabrication of multi-enzyme systems with controlled spatial arrangements and precise positions (Table 4), which can improve

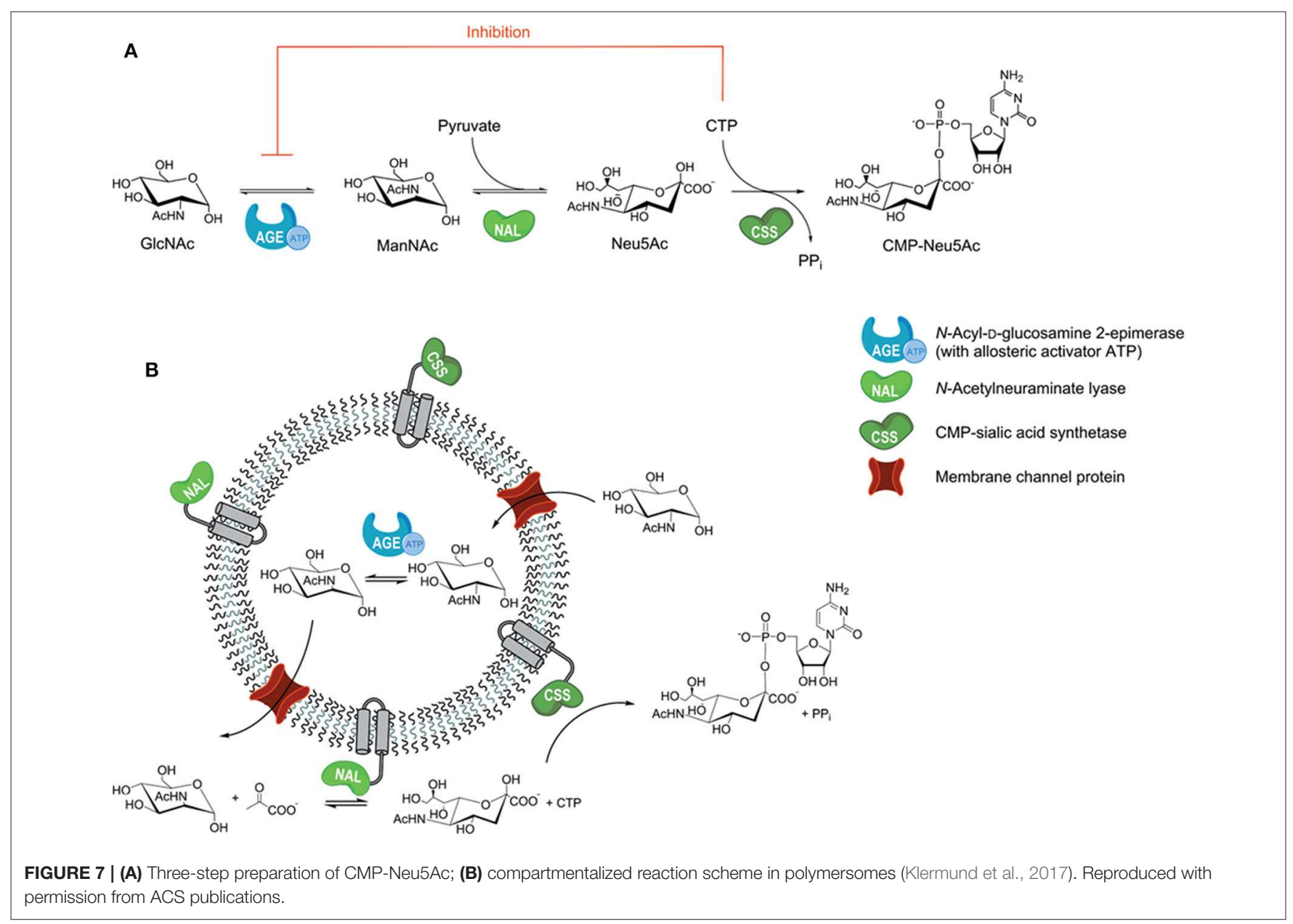


enzyme cascade catalytic efficiency via substrate channeling. However, due to the operation difficulty and high cost, this promising technology can hardly meet the requirements of large-scale industry applications in the current stage. With the development of DNA nanotechnology, it is believed that the problems will be solved and DNA nanostructures will gradually enter the practical applications in the near future.

\section{Polymers}

Polymers with flexibility and diversity can be rationally designed based on the enzyme characteristics, which have been proved as one of the most promising materials for enzyme immobilization. They have several beneficial properties, such as good colloidal and mechanical stability, tailored permeability, and stimuli responsiveness (Bermudez et al., 2002; Du and O'Reilly, 2009; Jochems et al., 2011). It has been demonstrated that polymers are one of the common-used traditional carriers for multienzyme immobilization and have been studied for a long time. For example, Liu et al. reported an amperometric biosensor for the detection of glucose and lactose via the co-immobilization of GOD, $\beta$-alactosidase, mutarotase in $\beta$-cyclodextrin polymer, and the three enzymes were cross-linked by the polymer (Liu et al., 1998). Herein, a series of recently reported polymer-based materials for enzymes co-immobilization will be introduced (Table 5), including polymersomes, polymer nanostructures, polymer films, etc.

Polymersomes (i.e., polymer-based liposomes) are selfassembled polymer shells composed of block copolymer amphiphiles (Discher et al., 1999), in which multiple enzymes can be blocked in the polymer vesicles. Polymersomes with reconstituted channel proteins can be designed rationally to be more suitable for multi-enzyme immobilization, which will improve the mass transfer efficiency of the cascade reaction. For example, a channel-equipped polymersomein-polymersome architecture has been constructed for multi-enzyme biocatalysis, where the passive protein channel (outer-membrane protein F) was embedded into the inner membrane to allow for molecule exchange (Siti et al., 2014). A porin-functionalized polymersome was prepared to avoid the incompatible reactions by compartmentalization, which served as a naturally selective barrier between substrates and inhibitors (Figure 7; Klermund et al., 2017). To separate the incompatible $\mathrm{N}$-acyl-D-glucosamine 2-epimerase (AGE) and CMP-sialic acid synthetase (CSS) reactions, the AGE was encapsulated in the lumen of poly(methyloxazoline) $15^{-}$ poly(dimethylsiloxane) 68 -poly(methyloxazoline) 15 (PMOXAPDMS-PMOXA) polymersomes (Figure 7B) during vesicle formation and nacetylneuraminate lyase (NAL) and the CSS were co-immobilized on the outer surface using hydrophobic peptide anchors. The three-step preparation (Figure 7A) of CMP-N-acetylneuraminic acid (CMP-Neu5Ac) from $\mathrm{N}$ acetylglucosamine (GlcNAc), pyruvate and cytidine triphosphate (CTP) was improved 2.2-fold compared to the free enzymes.

Polymer nanostructures (such as nanoparticles and nanofibers) have also been used as carriers for the fabrication of multi-enzyme systems. Wang's group prepared polystyrene particles to co-immobilize formate dehydrogenase (FDH), formaldehyde dehydrogenase (FaldDH), alcohol dehydrogenase $(\mathrm{ADH})$, glutamate dehydrogenase $(\mathrm{GDH})$, and cofactor $\mathrm{NADH} / \mathrm{NAD}^{+}$, which achieved efficient cofactor regeneration for the synthesis of methanol from $\mathrm{CO}_{2}$ (El-Zahab et al., 2008). Similarly, polyglycidyl methacrylate (PGMA) spheres were also used for the co-immobilization of GOx and catalase for the preparation of gluconic acid from glucose (Liao et al., 2019). Zhang's group fabricated a polyurethane hollow nanofiber via a co-axial electrospinning technique, which could be used for the co-immobilization of 3a-hydroxysteroid dehydrogenase (3a-HSD), diaphorase (DP), and NADH (Ji et al., 2014). In this multi-enzyme system, bile acids was oxidized and 2,6-dichlorophenolindophenol was reduced with cofactor regeneration, which presented $75 \%$ recovery activity and more than a 170 -fold increase in half-life at $25^{\circ} \mathrm{C}$.

A suitable polymer film was also exploited to co-immobilize $\beta$-glucosidase (BG) and cellulose for the production of glucose from cellulose, which was formed by visible-light-induced graft polymerization (Wang Y. et al., 2019). The layered polyethylene (LDPE) film consisted of a thin PEG hydrogel (as the inner layer) and a sodium polyacrylate (PAANa) brush (as the outer layer), where BG/cellulose was immobilized in/on the inner/outer layer, respectively. The resultant dual-enzyme system exhibited 82 and $20 \%$ increase in catalytic activity, compared with the single cellulase system and isolated BG/cellulase immobilized system, respectively. Moreover, 93\% of carboxymethylcellulose sodium salt (CMC) activity could be maintained after 10 cycles of hydrolysis, exhibiting excellent reusability.

Moreover, the dendronized polymers (Grotzky et al., 2012), polydopamine microcapsules (Zhang et al., 2011), and polymer hybrid hydrogels (Wei et al., 2016) have also been synthesized for the multi-enzyme immobilization. For example, hybrid hydrogels were fabricated by dual enzyme (GOx and HRP) mediated redox initiation polymerization, which combined the merits of higher mechanical strength and porous networks (Wei et al., 2016). The immobilized GOx/HRP in the hybrid hydrogels revealed super activity, as indicated by the highest $k_{\text {cat }}$ value $\left(7.348 \mathrm{~s}^{-1}\right)$, which is approximately $1.16 \pm 0.05$ times higher than that of the free GOx/HRP $\left(6.340 \mathrm{~s}^{-1}\right)$.

In the past several decades, it has been demonstrated that polymer-based materials are ideal support materials for multi-enzyme immobilization due to their good mechanical strength, easily adjustable morphologies and stable properties (Table 5). However, some limitations/problems still existed in the polymers based multi-enzyme immobilization systems, including the unprecise arrangement of different enzymes and the loss of chemical groups from the carriers. Even though, polymer-based materials are still one of the most commonused traditional supports for multi-enzyme immobilization in the industrial/practical applications.

\section{Silica}

Silica $\left(\mathrm{SiO}_{2}\right)$ materials are one of the widely used mesoporous structures with various applications (Zhou and Hartmann, 2013), which possess ordered pore structure, narrow pore size distribution, large specific surface area $\left(\sim 1,000 \mathrm{~m}^{2} \mathrm{~g}^{-1}\right)$ and high stability. Thus, mesoporous silica have attracted reasonable 
attention as the enzyme immobilization supports (Magner, 2013), and their unique features also suggest that they are ideal supports for multi-enzyme immobilization. For example, Van Aken et al. reported the case of co-immobilization of manganese peroxidase and glucose oxidase on porous aminoalkylethoxysilane activated silica beads by glutaraldehyde assisted covalent bindings, which was used for the production of gluconic acid from glucose (Van Aken et al., 2000). Silica materials are one of the traditional enzyme co-immobilization carriers and have been studied for a long time (Cho et al., 2012). Herein, some recent important works for multi-enzyme immobilization based on $\mathrm{SiO}_{2}$ carriers with different morphology will be provided (Table 6), including microcapsules, colloidosomes, core-shell nanoparticles etc.

A ultrathin, hybrid silica microcapsule was designed to construct an efficient multi-enzyme system for the production of methanol from $\mathrm{CO}_{2}$ (Wang et al., 2014), which was prepared through the deposition of catechol-modified gelatin, followed by in situ growth of silica nanoparticles on the gelatin layer. Formate dehydrogenase (FateDH), formaldehyde dehydrogenase (FaldDH), and alcohol dehydrogenase (YADH) were immobilized through physical entrapment in the microcapsule

TABLE 6 | Examples of multi-enzyme immobilization systems based on silica.

\begin{tabular}{|c|c|c|c|c|}
\hline Materials & Model enzymes & Applications & $\begin{array}{l}\text { Types of } \\
\text { multi-immobilization }\end{array}$ & References \\
\hline $\begin{array}{l}\text { Aminoalkylethoxysilane activated } \\
\text { silica beads }\end{array}$ & GOx and HRP & $\begin{array}{l}\text { Preparation of gluconic acid } \\
\text { from glucose }\end{array}$ & Random co-immobilization & Van Aken et al., 2000 \\
\hline $\begin{array}{l}\text { Catechol-modified gelatin-silica } \\
\text { microcapsules }\end{array}$ & FateDH, FaldDH and YADH & $\begin{array}{l}\text { Preparation of methanol } \\
\text { from } \mathrm{CO}_{2}\end{array}$ & Compartmentalization & Wang et al., 2014 \\
\hline Nanoscale silica layers & $\begin{array}{l}\text { Cellulase, glucokinase and } \\
\text { phosphoglucose dehydrogenase }\end{array}$ & $\begin{array}{l}\text { Preparation of cellobiose } \\
\text { from } \\
6 \text {-phosphogluconolactone }\end{array}$ & Compartmentalization & Begum et al., 2015 \\
\hline $\begin{array}{l}\text { Poly(acrylic acid) brushes-nano } \\
\text { spherical silica }\end{array}$ & GOx and HRP & Detection of glucose & Random co-immobilization & Zhao et al., 2016 \\
\hline $\mathrm{SiO}_{2}$ nanoparticle colloidosomes & GOx and lignin peroxidase & $\begin{array}{l}\text { Preparation of ethyl acetate } \\
\text { from pyridine- } \mathrm{N} \text {-oxide }\end{array}$ & Compartmentalization & Liu et al., 2018 \\
\hline $\begin{array}{l}\text { Core-shell magnetic } \mathrm{SiO}_{2} \text { hybrid } \\
\text { nanoparticles }\end{array}$ & Cellulase and lysozyme & $\begin{array}{l}\text { Biocatalysis (cell-walls } \\
\text { degradation) }\end{array}$ & Random co-immobilization & Chen Q. et al., 2018 \\
\hline $\begin{array}{l}\text { Amino-modified } \mathrm{Fe}_{3} \mathrm{O}_{4} / \mathrm{SiO}_{2} \\
\text { core-shell nanospheres }\end{array}$ & Glucoamylase and $\alpha$-amylase & $\begin{array}{l}\text { Preparation of glucose from } \\
\text { starch }\end{array}$ & Random co-immobilization & Bian et al., 2018 \\
\hline
\end{tabular}

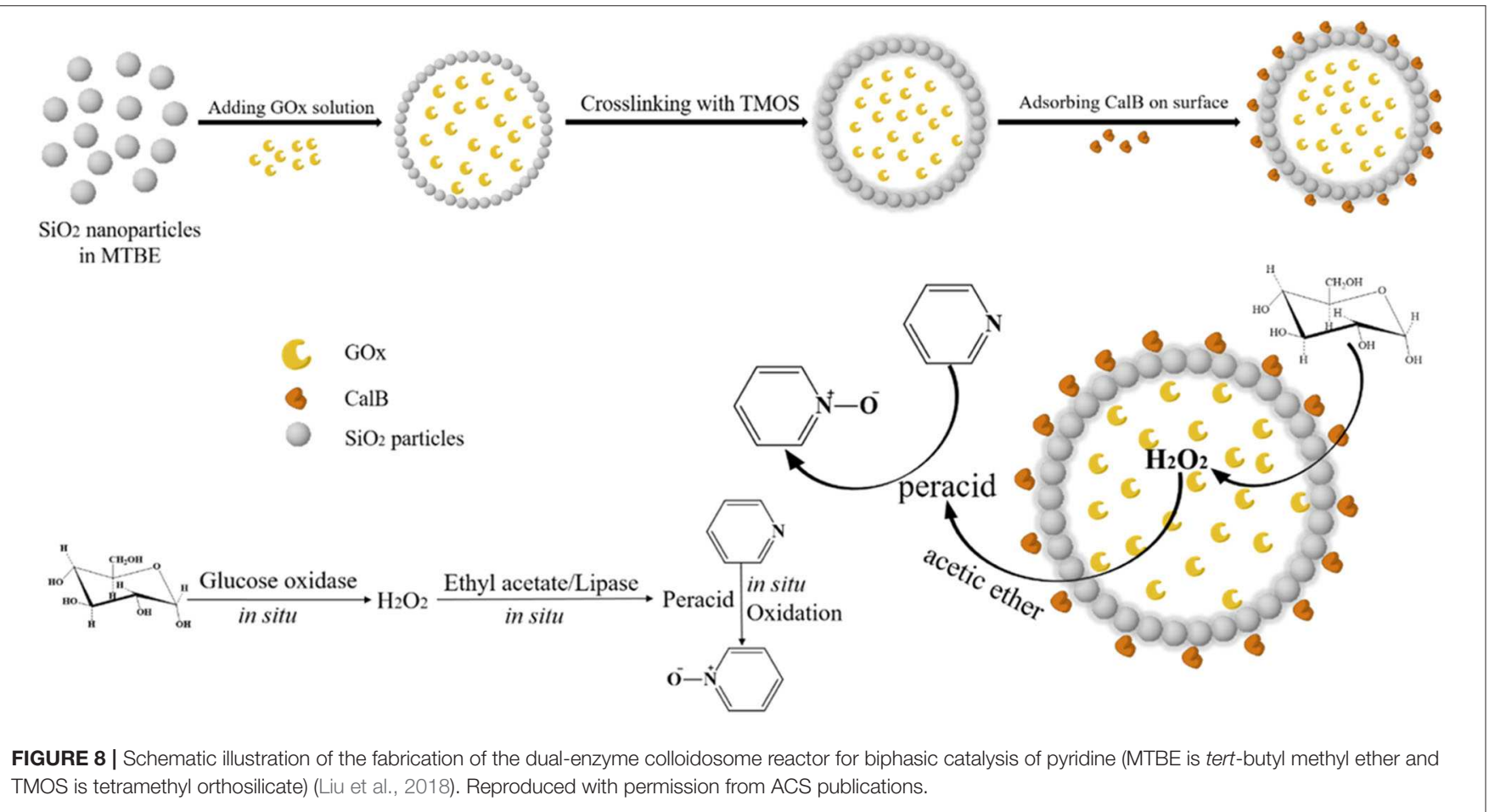


lumen, covalent attachment onto the catechol-modified gelatin layer, and physical entrapment in the silica layer, respectively. The ordered assembly of enzymes and the adjustable pore sizes of the scaffold facilitated the direct transfer of an intermediate between consecutive enzymes, resulting remarkably higher yield (71.6\%) and selectivity (86.7\%) of catalysis systems than that of free enzymes (35.5\% yield and $47.3 \%$ selectivity). Moreover, this multi-enzyme co-immobilized system exhibited good recyclability with $52.6 \%$ yield retention after 9 recycles. Similarly, nanoscale silica layers coated diatom silica microparticles were designed for the fabrication of an artificial enzyme cascade system, in which three hexaarginine-tagged enzymes (i.e., cellulase, glucokinase, and phosphoglucose dehydrogenase) were co-immobilized in the five layers of silica via peptide-mediated layer-by-layer mineralization (Begum et al., 2015). Moreover, a poly(acrylic acid) brushes-nanospherical silica was also used as co-immobilized support for the construction of a bienzymatic biosensor for glucose detection (Zhao et al., 2016).

A colloidosome composed of $\mathrm{SiO}_{2}$ nanoparticles was synthesized as the microreactor for dualenzyme cascade biphasic reaction (Figure 8), in which GOx was compartmentalized inside the colloidosome and Candida antarctica lipase (CalB) was adsorbed on the outer surfaces of the colloidosome (Liu et al., 2018). Glucose, as the energy source, was catalyzed by GOx to produce hydrogen peroxide $\left(\mathrm{H}_{2} \mathrm{O}_{2}\right)$ and $\mathrm{H}_{2} \mathrm{O}_{2}$ diffused out of the microcapsules was employed by CalB to catalyze the perhydrolysis of ethyl acetate. The generated peracids could oxidize of N-heteroaromatic compounds in situ. The bioinspired dual-enzyme amphiphilic colloidosome reactor showed high biphasic catalytic performance of pyridine, and no obvious yield decline was observed in the four cycles.

Core-shell magnetic silica hybrid nanoparticles have also been designed through coating silica shell on the surface of magnetic core, which exhibited large specific surface area and easy recovery (Chen Q. et al., 2018). Cellulase and lysozyme were co-immobilized on the surface of amino-functionalized magnetic nanoparticles, which showed greater thermal stability and wider $\mathrm{pH}$ tolerance than free enzymes under harsh conditions. Similarly, $\alpha$-amylase and glucoamylase were covalently co-immobilized on amino-modified $\mathrm{Fe}_{3} \mathrm{O}_{4} / \mathrm{SiO}_{2}$ core-shell nanospheres with a $\mathrm{Fe}^{3+}$-tannic acid film for one-pot starch hydrolysis (Bian et al., 2018).

In the past several decades, it has been demonstrated that silica-based materials are ideal supports for multi-enzyme immobilization (Table 6), due to their ordered pore structures, narrow pore size distributions and large specific surface areas. However, some limitations/problems still exist in the silica based multi-enzyme immobilization systems, including the easy enzymes leaching and unprecise arrangement of different enzymes. A major development direction may be the formation of composites with other materials (such as MOF and DNA), which will improve the immobilized efficiency or substrate channeling of silica-based multi-enzyme systems.

\section{Others}

In addition to the above 6 main support materials, other carriers (such as metal, $\mathrm{TiO}_{2}$ and natural polymers) have also been used for the fabrication of efficient multi-enzyme systems (Table 7).

Porous metal nanoparticles (e.g., gold and silver) have been used as co-immobilized carriers for different enzymes. Lignin peroxidase and GOx were co-immobilized on the surface of nanoporous gold via physical adsorption, which exhibited good potentials in biocatalysis and biosensing (Qiu et al., 2009). GOx and glucoamylase were covalently attached to the amino modified dendritic Ag hierarchical nanostructure for the efficient one-pot conversion of starch into gluconic acid (Rezaei et al., 2019), and the resultant multi-enzyme system exhibited high total activity and reusability over a wide range of $\mathrm{pH}$ and temperature values.

$\mathrm{TiO}_{2}$ based structures (e.g., $\mathrm{TiO}_{2}$ nanoparticles and $\mathrm{TiO}_{2}$ hybrid microcapsules) have also been utilized as support

TABLE 7 | Examples of multi-enzyme immobilization systems based on other materials.

\begin{tabular}{|c|c|c|c|c|}
\hline Materials & Model enzymes & Applications & $\begin{array}{l}\text { Types of } \\
\text { multi-immobilization }\end{array}$ & References \\
\hline Nanoporous gold & GOx and lignin peroxidase & $\begin{array}{l}\text { Preparation of gluconic acid } \\
\text { from glucose }\end{array}$ & Random co-immobilization & Qiu et al., 2009 \\
\hline $\begin{array}{l}\text { Amino-modified silver dendritic } \\
\text { hierarchical nanostructure }\end{array}$ & GOx and glucoamylase & $\begin{array}{l}\text { Preparation of gluconic acid } \\
\text { from starch }\end{array}$ & Random co-immobilization & Rezaei et al., 2019 \\
\hline $\begin{array}{l}\text { OilGOxopa-functionalized } \mathrm{TiO}_{2} \\
\text { nanoparticles }\end{array}$ & $\begin{array}{l}\text { Formate dehydrogenase and } \\
\text { formaldehyde dehydrogenase }\end{array}$ & $\begin{array}{l}\text { Preparation of formaldehyde } \\
\text { from } \mathrm{CO}_{2}\end{array}$ & Compartmentalization & Shi et al., 2012 \\
\hline $\begin{array}{l}\mathrm{PDA}-\mathrm{PEI} / \mathrm{TiO}_{2} \text { hybrid } \\
\text { microcapsules }\end{array}$ & GOx, catalase & $\begin{array}{l}\text { Preparation of gluconic acid } \\
\text { from glucose }\end{array}$ & Random co-immobilization & Shi et al., 2015 \\
\hline $\begin{array}{l}\text { Agarose beads modified by } \\
\text { glyoxyl and boronate }\end{array}$ & $\begin{array}{l}\text { NADH oxidase, formate } \\
\text { dehydrogenase and peroxidase }\end{array}$ & $\begin{array}{l}\text { Preparation of insoluble } \\
\text { phenolic derivatives from } \\
\text { aromatic compound } \\
\text { (phenol, 2,4-dichlorophenol, } \\
\text { 4-aminophenol or } \\
\alpha \text {-naphthol), formic acid }\end{array}$ & Random co-immobilization & $\begin{array}{l}\text { Rocha-Martin et al., } \\
2014\end{array}$ \\
\hline Octyl-modified agarose & Lipase and $\beta$-galactosidase & $\begin{array}{l}\text { Preparation of galactose } \\
\text { from triacetin and lactose }\end{array}$ & Compartmentalization & Peirce et al., 2016 \\
\hline
\end{tabular}


materials for multi-enzyme immobilization. A separated multienzyme system based on $\mathrm{TiO}_{2}$ nanoparticles was constructed for converting $\mathrm{CO}_{2}$ to formaldehyde, in which formate dehydrogenase was entrapped in the $\mathrm{TiO}_{2}$ nanoparticles during the material formation and formaldehyde dehydrogenase was immobilized on the surface (Shi et al., 2012). It was found that smaller nanoparticle-based multi-enzyme system displayed higher specific activity, yield and selectivity, while larger ones exhibited superior recycling stability. Similarly, catalase and GOx were encapsulated in the polydopamine-polyethylenimine (PDA$\mathrm{PEI} / \mathrm{TiO}_{2}$ hybrid microcapsules for efficient biocatalysis and biosensing (Shi et al., 2015).

Due to the good biocompatibility, low price and biodegradability, natural polymers (e.g., agarose) have been used as multi-enzyme immobilized supports for decades (Liu et al., 2002; Shao et al., 2002). Recently, formate dehydrogenase and NADH-oxidase were co-immobilized onto glyoxyl activated agarose beads and peroxidase was immobilized onto the boronate activated agarose for the fabrication of the multienzyme biocatalyst (Rocha-Martin et al., 2014), which can oxidize phenols using oxygen and formic acid as substrates without undesired by-products. A hetero-functional octylagarose support for multi-enzyme immobilization was also developed for the preparation of galactose from triacetin and lactose, in which lipase and $\beta$-galactosidase were co-immobilized on the hydrophobic surface of the supports via different immobilization strategies (Peirce et al., 2016).

\section{CONCLUSION}

In this review, a series of recent support materials and their corresponding attachment techniques for multi-enzyme immobilization have been presented. Six main catalogs of supports for the fabrication of multi-enzyme systems have been

\section{REFERENCES}

Ansari, S. A., and Husain, Q. (2012). Potential applications of enzymes immobilized on/in nano materials: a review. Biotechnol. Adv. 30, 512-523. doi: 10.1016/j.biotechadv.2011.09.005

Asuri, P., Karajanagi, S. S., Yang, H., Yim, T.-J., Kane, R. S., and Dordick, J. S. (2006). Increasing protein stability through control of the nanoscale environment. Langmuir 22, 5833-5836. doi: 10.1021/la05 28450

Barnes, S. J., and Weitzman, P. D. J. (1986). Organization of citric acid cycle enzymes into a multienzyme cluster. FEBS J. 201, 267-270. doi: 10.1016/0014-5793(86)80621-4

Begum, G., Goodwin, W. B., Deglee, B. M., Sandhage, K. H., and Kröger, N. (2015). Compartmentalisation of enzymes for cascade reactions through biomimetic layer-by-layer mineralization. J. Mater. Chem. B 3, 5232-5240. doi: 10.1039/C5TB00333D

Bermudez, H., Brannan, A. K., Hammer, D. A., Bates, F. S., and Discher, D. E. (2002). Molecular weight dependence of polymersome membrane structure, elasticity, and stability. Macromolecules 35, 8203-8208. doi: 10.1021/ma020669l

Bi, S., Zhou, H., and Zhang, S. (2009). Multilayers enzyme-coated carbon nanotubes as biolabel for ultrasensitive chemiluminescence immunoassay of cancer biomarker. Biosens. Bioelectron. 24, 2961-2966. doi: 10.1016/j.bios.2009.03.002 overviewed, including graphene and its derivatives, CNTs, MOFs, DNA nanostructures, polymers, and silica. In addition, three main techniques for multi-enzyme immobilization have also been discussed, including random co-immobilization, positional co-immobilization, and compartmentalization. By the mimic of multiple enzyme arrangement in cells in vivo, co-immobilized enzymes can catalyze raw materials to synthesize many valuable products in vitro, such as pharmaceuticals, cosmetics, and nutrition. Support materials not only can serve as scaffold, but also regulate the catalytic properties of enzymes, which will increase the enzymatic activity via substrate channeling and improve the stability and reusability of enzymes. However, co-immobilized multi-enzyme biocatalysis still faces some problems, such as precisely controlling the synthetic substrate channeling, lowering the overall production costs, developing greener and more biocompatible supports. In the future, the design of a co-immobilized multi-enzyme catalysis system with high catalytic efficiency, reusability, and practical operations will be the research priority in the fields of biotechnology and bioengineering.

\section{AUTHOR CONTRIBUTIONS}

KX wrote and revised the manuscript under the guidance of $\mathrm{RZ}$ and YZ. XC helped to draw the figures and write the manuscript. All authors contributed to the article and approved the submitted version.

\section{FUNDING}

This work was supported by the National Key Research and Development Project (No. 2017YFE0129400) and Natural Science Foundation of Zhejiang Province (Nos. LR19B060001 and LQ20E020009).
Bian, H., Sun, B., Cui, J., Ren, S., Lin, T., Feng, Y., et al. (2018). Bienzyme magnetic nanobiocatalyst with $\mathrm{Fe}^{3+}$-tannic acid film for one-pot starch hydrolysis. $J$ Agric. Food Chem. 66, 8753-8760. doi: 10.1021/acs.jafc.8b02097

Britton, J., Majumdar, S., and Weiss, G. A. (2018). Continuous flow biocatalysis. Chem. Soc. Rev. 47, 5891-5918. doi: 10.1039/C7CS00906B

Burnett, B. J., Barron, P. M., and Choe, W. (2012). Recent advances in porphyrinic metal-organic frameworks: materials design, synthetic strategies, and emerging applications. CrystEngComm 14, 3839-3846. doi: 10.1039/c2ce06692k

Cao, Y., Li, X., Xiong, J., Wang, L., Yan, L.-T., and Ge, J. (2019). Investigating the origin of high efficiency in confined multienzyme catalysis. Nanoscale 11, 22108-22117. doi: 10.1039/C9NR07381G

Chang, Q., Jiang, G., Tang, H., Li, N., Huang, J., and Wu, L. (2015). Enzymatic removal of chlorophenols using horseradish peroxidase immobilized on superparamagnetic $\mathrm{Fe}_{3} \mathrm{O}_{4}$ /graphene oxide nanocomposite. Chin. J. Catal. 36, 961-968. doi: 10.1016/S1872-2067(15)60856-7

Chen, Q., Liu, D., Wu, C., Yao, K., Li, Z., Shi, N., et al. (2018). Co-immobilization of cellulase and lysozyme on amino-functionalized magnetic nanoparticles: an activity-tunable biocatalyst for extraction of lipids from microalgae. Bioresour. Technol. 263, 317-324. doi: 10.1016/j.biortech.2018.04.071

Chen, S. J., Wen, L. Y., Svec, F., Tan, T. W., and Lv, Y. Q. (2017). Magnetic metalorganic frameworks as scaffolds for spatial co-location and positional assembly of multi-enzyme systems enabling enhanced cascade biocatalysis. RSC Adv. 7, 21205-21213. doi: 10.1039/C7RA02291C 
Chen, Y., Ke, G., Ma, Y., Zhu, Z., Liu, M., Liu, Y., et al. (2018). A synthetic light-driven substrate channeling system for precise regulation of enzyme cascade activity based on DNA origami. J. Am. Chem. Soc. 140, 8990-8996. doi: 10.1021/jacs.8b05429

Cho, E. J., Jung, S., Kim, H. J., Lee, Y. G., Nam, K. C., Lee, H.-J., et al. (2012). Co-immobilization of three cellulases on Au-doped magnetic silica nanoparticles for the degradation of cellulose. Chem. Commun. 48, 886-888. doi: $10.1039 / \mathrm{C} 2 \mathrm{CC} 16661 \mathrm{E}$

Dai, H. (2002). Carbon nanotubes: synthesis, integration, and properties. Acc. Chem. Res. 35, 1035-1044. doi: 10.1021/ar0101640

Das, P., Mandal, B., and Gumma, S. (2020). Engineering of structural and surface functional characteristics of graphite oxide nanosheets by controlling oxidation temperature. Appl. Surf. Sci. 504:144444. doi: 10.1016/j.apsusc.2019.144444

Deng, H. X., Grunder, S., Cordova, K. E., Valente, C., Furukawa, H., Hmadeh, M., et al. (2012). Large-pore apertures in a series of metal-organic frameworks. Science 336, 1018-1023. doi: 10.1126/science.1220131

Dey, C., Kundu, T., Biswal, B. P., Mallick, A., and Banerjee, R. (2014). Crystalline metal-organic frameworks (MOFs): synthesis, structure and function. Acta Crystallogr. B Struct. Sci. Crystal Eng. Mater. 70, 3-10. doi: $10.1107 /$ S2052520613029557

Dey, R. S., and Raj, C. R. (2014). Enzyme-integrated cholesterol biosensing scaffold based on in situ synthesized reduced graphene oxide and dendritic Pd nanostructure. Biosens. Bioelectron. 62, 357-364. doi: 10.1016/j.bios.2014.06.063

Discher, B. M., Won, Y.-Y., Ege, D. S., Lee, J. C.-M., Bates, F. S., Discher, D. E., et al. (1999). Polymersomes: tough vesicles made from diblock copolymers. Science 284, 1143-1146. doi: 10.1126/science.284.5417.1143

Du, J., and O'Reilly, R. K. (2009). Advances and challenges in smart and functional polymer vesicles. Soft Matter 5, 3544-3561. doi: 10.1039/b905635a

Dubey, N. C., Tripathi, B. P., Müller, M., Stamm, M., and Ionov, L. (2016). Bienzymatic sequential reaction on microgel particles and their cofactor dependent applications. Biomacromolecules 17, 1610-1620. doi: 10.1021/acs.biomac.5b01745

Ebbesen, T. W. (1996). Carbon nanotubes. Phys. Today 49, 26-32. doi: $10.1063 / 1.881603$

El-Zahab, B., Donnelly, D., and Wang, P. (2008). Particle-tethered NADH for production of methanol from $\mathrm{CO}_{2}$ catalyzed by coimmobilized enzymes. Biotechnol. Bioeng. 99, 508-514. doi: 10.1002/bit.21584

Fang, Y., Bullock, H., Lee, S. A., Sekar, N., Eiteman, M. A., Whitman, W. B., et al. (2016). Detection of methyl salicylate using bi-enzyme electrochemical sensor consisting salicylate hydroxylase and tyrosinase. Biosens. Bioelectron. 85 , 603-610. doi: 10.1016/j.bios.2016.05.060

Fu, J., Yang, Y. R., Johnson-Buck, A., Liu, M., Liu, Y., Walter, N. G., et al. (2014). Multi-enzyme complexes on DNA scaffolds capable of substrate channelling with an artificial swinging arm. Nat. Nanotechnol. 9, 531-536. doi: 10.1038/nnano.2014.100

Fu, J. L., Liu, M. H., Liu, Y., Woodbury, N. W., and Yan, H. (2012). Interenzyme substrate diffusion for an enzyme cascade organized on spatially addressable DNA nanostructures. J. Am. Chem. Soc. 134, 5516-5519. doi: $10.1021 /$ ja300897h

Fu, Y., Zeng, D., Chao, J., Jin, Y., Zhang, Z., Liu, H., et al. (2013). Single-step rapid assembly of DNA origami nanostructures for addressable nanoscale bioreactors. J. Am. Chem. Soc. 135, 696-702. doi: 10.1021/ja 3076692

Furukawa, H., Cordova, K. E., O’keeffe, M., and Yaghi, O. M. (2013). The chemistry and applications of metal-organic frameworks. Science 341, 1-12. doi: $10.1126 /$ science. 1230444

Gao, Y., and Kyratzis, I. (2008). Covalent immobilization of proteins on carbon nanotubes using the cross-linker 1-Ethyl-3-(3dimethylaminopropyl)carbodiimide-a critical assessment. Bioconjug. Chem. 19, 1945-1950. doi: 10.1021/bc800051c

Geim, A. K., and Novoselov, K. S. (2007). The rise of graphene. Nat. Mater. 6, 183-191. doi: 10.1038/nmat1849

Giannakopoulou, A., Gkantzou, E., Polydera, A., and Stamatis, H. (2020). Multienzymatic nanoassemblies: recent progress and applications. Trends Biotechnol. 38, 202-216. doi: 10.1016/j.tibtech.2019.07.010

Grotzky, A., Nauser, T., Erdogan, H., Schluter, A. D., and Walde, P. (2012). A fluorescently labeled dendronized polymer-enzyme conjugate carrying multiple copies of two different types of active enzymes. J. Am. Chem. Soc. 134, 11392-11395. doi: 10.1021/ja304837f

Hu, Y., Dai, L., Liu, D., Du, W., and Wang, Y. (2018). Progress \& prospect of metalorganic frameworks (MOFs) for enzyme immobilization (enzyme/MOFs). Renew. Sust. Energy Rev. 91, 793-801. doi: 10.1016/j.rser.2018.04.103

Huang, Y., Wang, W., Li, Z., Qin, X. L., Bu, L. J., Tang, Z. Y., et al. (2013). Horseradish peroxidase-catalyzed synthesis of poly(thiophene-3-boronic acid) biocomposites for mono-/bi-enzyme immobilization and amperometric biosensing. Biosens. Bioelectron. 44, 41-47. doi: 10.1016/j.bios.2013.01.001

Huffman, M. A., Fryszkowska, A., Alvizo, O., Borra-Garske, M., Campos, K. R., Canada, K. A., et al. (2019). Design of an in vitro biocatalytic cascade for the manufacture of islatravir. Science 366, 1255-1259. doi: 10.1126/science.aay8484

Hwang, E. T., and Lee, S. (2019). Multienzymatic cascade reactions via enzyme complex by immobilization. ACS Catal. 9, 4402-4425. doi: 10.1021/acscatal.8b04921

Ji, X., Wang, P., Su, Z., Ma, G., and Zhang, S. (2014). Enabling multi-enzyme biocatalysis using coaxial-electrospun hollow nanofibers: redesign of artificial cells. J. Mater. Chem. B 2, 181-190. doi: 10.1039/C3TB21232G

Jia, F., Mallapragada, S. K., and Narasimhan, B. (2015). Multienzyme immobilization and colocalization on nanoparticles enabled by DNA hybridization. Ind. Eng. Chem. Res. 54, 10212-10220. doi: 10.1021/acs.iecr.5b01423

Jia, F., Narasimhan, B., and Mallapragada, S. (2014). Materials-based strategies for multi-enzyme immobilization and co-localization: a review. Biotechnol. Bioeng. 111, 209-222. doi: 10.1002/bit.25136

Jochems, P., Satyawali, Y., Diels, L., and Dejonghe, W. (2011). Enzyme immobilization on/in polymeric membranes: status, challenges and perspectives in biocatalytic membrane reactors (BMRs). Green Chem. 13, 1609-1623. doi: 10.1039/c1gc15178a

Klein, W. P., Thomsen, R. P., Turner, K. B., Walper, S. A., Vranish, J., Kjems, J., et al. (2019). Enhanced catalysis from multienzyme cascades assembled on a DNA origami triangle. ACS Nano 13, 13677-13689. doi: 10.1021/acsnano.9b05746

Klermund, L., Poschenrieder, S. T., and Castiglione, K. (2017). Biocatalysis in polymersomes: improving multienzyme cascades with incompatible reaction steps by compartmentalization. ACS Catal. 7, 3900-3904. doi: 10.1021/acscatal.7b00776

Kou, B., Chai, Y., Yuan, Y., and Yuan, R. (2018). Dynamical regulation of enzyme cascade amplification by a regenerated DNA nanotweezer for ultrasensitive electrochemical DNA detection. Anal. Chem. 90, 10701-10706. doi: 10.1021/acs.analchem.8b00477

Lang, Q., Yin, L., Shi, J., Li, L., Xia, L., and Liu, A. (2014). Co-immobilization of glucoamylase and glucose oxidase for electrochemical sequential enzyme electrode for starch biosensor and biofuel cell. Biosens. Bioelectron. 51, 158-163. doi: 10.1016/j.bios.2013.07.021

Li, F., Ma, W., Liu, J., Wu, X., Wang, Y., and He, J. (2018). Luminol, horseradish peroxidase, and glucose oxidase ternary functionalized graphene oxide for ultrasensitive glucose sensing. Anal. Bioanal. Chem. 410, 543-552. doi: 10.1007/s00216-017-0752-5

Li, Y., Wen, L. Y., Tan, T. W., and Lv, Y. Q. (2019). Sequential coimmobilization of enzymes in metal-organic frameworks for efficient biocatalytic conversion of adsorbed $\mathrm{CO}_{2}$ to formate. Front. Bioeng. Biotechnol. 7:394. doi: 10.3389/fbioe.2019.00394

Li, Z., Zhang, Y., Su, Y., Ouyang, P., Ge, J., and Liu, Z. (2014). Spatial colocalization of multi-enzymes by inorganic nanocrystal-protein complexes. Chem. Commun. 50, 12465-12468. doi: 10.1039/C4CC05478D

Lian, X., Chen, Y. P., Liu, T. F., and Zhou, H. C. (2016). Coupling two enzymes into a tandem nanoreactor utilizing a hierarchically structured MOF. Chem. Sci. 7, 6969-6973. doi: 10.1039/C6SC01438K

Lian, X., Fang, Y., Joseph, E., Wang, Q., Li, J., Banerjee, S., et al. (2017). EnzymeMOF (metal-organic framework) composites. Chem. Soc. Rev. 46, 3386-3401. doi: $10.1039 / \mathrm{C} 7 \mathrm{CS} 00058 \mathrm{H}$

Liang, S., Wu, X.-L., Xiong, J., Zong, M.-H., and Lou, W.-Y. (2020). Metal-organic frameworks as novel matrices for efficient enzyme immobilization: an update review. Coord. Chem. Rev. 406:213149. doi: 10.1016/j.ccr.2019.213149

Liao, L., Meng, Y., Wang, R., Jia, B., and Li, P. (2019). Coupling and regulation of porous carriers using plasma and amination to improve the catalytic performance of glucose oxidase and catalase. Front. Bioeng. Biotechnol. 7:426 doi: 10.3389/fbioe.2019.00426 
Liu, H., Li, H., Ying, T., Sun, K., Qin, Y., and Qi, D. (1998). Amperometric biosensor sensitive to glucose and lactose based on co-immobilization of ferrocene, glucose oxidase, $\beta$-galactosidase and mutarotase in $\beta$-cyclodextrin polymer. Anal. Chim. Acta 358, 137-144. doi: 10.1016/S0003-2670(97)00576-X

Liu, Y., Du, J., Yan, M., Lau, M. Y., Hu, J., Han, H., et al. (2013). Biomimetic enzyme nanocomplexes and their use as antidotes and preventive measures for alcohol intoxication. Nat. Nanotechnol. 8, 187-192. doi: 10.1038/nnano.2012.264

Liu, Z., Wang, B., Jin, S., Wang, Z., Wang, L., and Liang, S. (2018). Bioinspired dual-enzyme colloidosome reactors for high-performance biphasic catalysis. ACS Appl. Mater. Interfaces 10, 41504-41511. doi: 10.1021/acsami.8b14321

Liu, Z. Y., Zhang, J. B., Chen, X., and Wang, P. G. (2002). Combined biosynthetic pathway for de novo production of UDP-galactose: catalysis with multiple enzymes immobilized on agarose beads. Chembiochem 3, 348-355. doi: 10.1002/1439-7633(20020402)3:4<348::AID-CBIC348>3.0.CO;2-K

Magner, E. (2013). Immobilisation of enzymes on mesoporous silicate materials. Chem. Soc. Rev. 42, 6213-6222. doi: 10.1039/c2cs35450k

Marguet, M., Bonduelle, C., and Lecommandoux, S. (2013). Multicompartmentalized polymeric systems: towards biomimetic cellular structure and function. Chem. Soc. Rev. 42, 512-529. doi: 10.1039/C2CS35312A

Mathesh, M., Liu, J., Barrow, C. J., and Yang, W. (2017). Graphene-oxide-based enzyme nanoarchitectonics for substrate channeling. Chem. A Eur. J. 23, 304-311. doi: 10.1002/chem.201604348

Mayer, S. F., Kroutil, W., and Faber, K. (2001). Enzyme-initiated domino (cascade) reactions. Chem. Soc. Rev. 30, 332-339. doi: 10.1039/b105493g

Mosbach, K., and Mattiasson, B. (1976). "[31] Multistep enzyme systems," in Methods in Enzymology, eds K. Mosbach (Amsterdam: Academic Press), 453-478. doi: 10.1016/S0076-6879(76)44033-8

Ngo, T. A., Nakata, E., Saimura, M., and Morii, T. (2016). Spatially organized enzymes drive cofactor-coupled cascade reactions. J. Am. Chem. Soc. 138, 3012-3021. doi: 10.1021/jacs.5b10198

Novoselov, K. S., Geim, A. K., Morozov, S. V., Jiang, D., Zhang, Y., Dubonos, S. V., et al. (2004). Electric field effect in atomically thin carbon films. Science 306, 666-669. doi: 10.1126/science.1102896

Pang, H. L., Liu, J., Hu, D., Zhang, X. H., and Chen, J. H. (2010). Immobilization of laccase onto 1-aminopyrene functionalized carbon nanotubes and their electrocatalytic activity for oxygen reduction. Electrochim. Acta 55, 6611-6616. doi: 10.1016/j.electacta.2010.06.013

Park, S., and Ruoff, R. S. (2009). Chemical methods for the production of graphenes. Nat. Nanotechnol. 4, 217-224. doi: 10.1038/nnano.2009.58

Peirce, S., Virgen-Ortíz, J. J., Tacias-Pascacio, V. G., Rueda, N., Bartolome-Cabrero, R., Fernandez-Lopez, L., et al. (2016). Development of simple protocols to solve the problems of enzyme coimmobilization. Application to coimmobilize a lipase and a $\beta$-galactosidase. RSC Adv. 6, 61707-61715. doi: 10.1039/C6RA10906C

Pinheiro, A. V., Han, D. R., Shih, W. M., and Yan, H. (2011). Challenges and opportunities for structural DNA nanotechnology. Nat. Nanotechnol. 6, 763-772. doi: 10.1038/nnano.2011.187

Qiu, H., Li, Y., Ji, G., Zhou, G., Huang, X., Qu, Y., et al. (2009). Immobilization of lignin peroxidase on nanoporous gold: enzymatic properties and in situ release of $\mathrm{H}_{2} \mathrm{O}_{2}$ by co-immobilized glucose oxidase. Bioresour. Technol. 100, 3837-3842. doi: 10.1016/j.biortech.2009.03.016

Ramakrishna, T. R. B., Nalder, T. D., Yang, W., Marshall, S. N., and Barrow, C. J. (2018). Controlling enzyme function through immobilisation on graphene, graphene derivatives and other two dimensional nanomaterials. J. Mater. Chem. B 6, 3200-3218. doi: 10.1039/C8TB00313K

Ratautas, D., Marcinkevičiene, L., Meškys, R., and Kulys, J. (2015). Mediatorless electron transfer in glucose dehydrogenase/laccase system adsorbed on carbon nanotubes. Electrochim. Acta 174, 940-944. doi: 10.1016/j.electacta.2015.06.063

Ren, S. Z., Li, C. H., Jiao, X. B., Jia, S. R., Jiang, Y. J., Bilal, M., et al. (2019). Recent progress in multienzymes co-immobilization and multienzyme system applications. Chem. Eng. J. 373, 1254-1278. doi: 10.1016/j.cej.2019.05.141

Rezaei, S., Landarani-Isfahani, A., Moghadam, M., Tangestaninejad, S., Mirkhani, V., and Mohammadpoor-Baltork, I. (2019). Development of a novel bienzymatic silver dendritic hierarchical nanostructure cascade catalytic system for efficient conversion of starch into gluconic acid. Chem. Eng. J. 356, 423-435. doi: 10.1016/j.cej.2018.09.046

Ricca, E., Brucher, B., and Schrittwieser, J. H. (2011). Multi-enzymatic cascade reactions: overview and perspectives. Adv. Synth. Catal. 353, 2239-2262. doi: $10.1002 /$ adsc. 201100256
Rocha-Martin, J., Velasco-Lozano, S., Guisan, J. M., and Lopez-Gallego, F. (2014). Oxidation of phenolic compounds catalyzed by immobilized multi-enzyme systems with integrated hydrogen peroxide production. Green Chem. 16, 303-311. doi: 10.1039/C3GC41456F

Rothemund, P. W. K. (2006). Folding DNA to create nanoscale shapes and patterns. Nature 440, 297-302. doi: 10.1038/nature04586

Salgaonkar, M., Nadar, S. S., and Rathod, V. K. (2018). Combi-metal organic framework (Combi-MOF) of alpha-amylase and glucoamylase for one pot starch hydrolysis. Int. J. Biol. Macromol. 113, 464-475. doi: 10.1016/j.ijbiomac.2018.02.092

Shao, J., Zhang, J., Nahálka, J., and Wang, P. G. (2002). Biocatalytic synthesis of uridine $5^{\prime}$-diphosphate $\mathrm{N}$-acetylglucosamine by multiple enzymes co-immobilized on agarose beads. Chem. Commun. 8, 2586-2587. doi: 10.1039/B207480J

Sheldon, R. A., and van Pelt, S. (2013). Enzyme immobilisation in biocatalysis: why, what and how. Chem. Soc. Rev. 42, 6223-6235. doi: 10.1039/C3CS60075K

Sheldon, R. A., and Woodley, J. M. (2018). Role of biocatalysis in sustainable chemistry. Chem. Rev. 118, 801-838. doi: 10.1021/acs.chemrev. $7 \mathrm{~b} 00203$

Shi, J., Wang, X., Jiang, Z., Liang, Y., Zhu, Y., and Zhang, C. (2012). Constructing spatially separated multienzyme system through bioadhesion-assisted bioinspired mineralization for efficient carbon dioxide conversion. Bioresour. Technol. 118, 359-366. doi: 10.1016/j.biortech.2012.04.099

Shi, J., Wu, Y., Zhang, S., Tian, Y., Yang, D., and Jiang, Z. (2018). Bioinspired construction of multi-enzyme catalytic systems. Chem. Soc. Rev. 47, 4295-4313. doi: 10.1039/C7CS00914C

Shi, J., Zhang, W., Zhang, S., Wang, X., and Jiang, Z. (2015). Synthesis of organicinorganic hybrid microcapsules through in situ generation of an inorganic layer on an adhesive layer with mineralization-inducing capability. J. Mater. Chem. B 3, 465-474. doi: 10.1039/C4TB01802H

Siti, W., De Hoog, H.-P. M., Fischer, O., Shan, W. Y., Tomczak, N., Nallani, M., et al. (2014). An intercompartmental enzymatic cascade reaction in channelequipped polymersome-in-polymersome architectures. J. Mater. Chem. B 2, 2733-2737. doi: 10.1039/C3TB21849J

Song, J., Shen, H., Yang, Y., Zhou, Z., Su, P., and Yang, Y. (2018). Multifunctional magnetic particles for effective suppression of non-specific adsorption and coimmobilization of multiple enzymes by DNA directed immobilization. J. Mater. Chem. B 6, 5718-5728. doi: 10.1039/C8TB $01842 \mathrm{~A}$

Sun, L. L., Gao, Y. J., Xu, Y., Chao, J., Liu, H. J., Wang, L. H., et al. (2017). Real-time imaging of single-molecule enzyme cascade using a DNA origami raft. J. Am. Chem. Soc. 139, 17525-17532. doi: 10.1021/jacs.7b09323

Talekar, S., Pandharbale, A., Ladole, M., Nadar, S., Mulla, M., Japhalekar, K., et al. (2013). Carrier free co-immobilization of alpha amylase, glucoamylase and pullulanase as combined cross-linked enzyme aggregates (combi-CLEAs): a trienzyme biocatalyst with one pot starch hydrolytic activity. Bioresour. Technol. 147, 269-275. doi: 10.1016/j.biortech.2013.08.035

Van Aken, B., Ledent, P., Naveau, H., and Agathos, S. N. (2000). Coimmobilization of manganese peroxidase from phlebia radiata and glucose oxidase from aspergillus niger on porous silica beads. Biotechnol. Lett. 22, 641-646. doi: 10.1023/A:1005631411951

Walcarius, A., Minteer, S. D., Wang, J., Lin, Y., and Merkoçi, A. (2013). Nanomaterials for bio-functionalized electrodes: recent trends. J. Mater. Chem. B 1, 4878-4908. doi: 10.1039/c3tb20881h

Wang, D., Chai, Y., Yuan, Y., and Yuan, R. (2019). Precise regulation of enzyme cascade catalytic efficiency with DNA tetrahedron as scaffold for ultrasensitive electrochemical detection of DNA. Anal. Chem. 91, 3561-3566. doi: 10.1021/acs.analchem.8b05407

Wang, L., Wei, L., Chen, Y., and Jiang, R. (2010). Specific and reversible immobilization of NADH oxidase on functionalized carbon nanotubes. $J$. Biotechnol. 150, 57-63. doi: 10.1016/j.jbiotec.2010.07.005

Wang, L., Zhang, H., Ching, C.-B., Chen, Y., and Jiang, R. (2012). Nanotube-supported bioproduction of 4-hydroxy-2-butanone via in situ cofactor regeneration. Appl. Microbiol. Biotechnol. 94, 1233-1241. doi: 10.1007/s00253-011-3699-z

Wang, X., Li, Z., Shi, J., Wu, H., Jiang, Z., Zhang, W., et al. (2014). Bioinspired approach to multienzyme cascade system construction for efficient carbon dioxide reduction. ACS Catal. 4, 962-972. doi: 10.1021/cs401096c 
Wang, Y., Li, Z., Wang, J., Li, J., and Lin, Y. (2011). Graphene and graphene oxide: biofunctionalization and applications in biotechnology. Trends Biotechnol. 29, 205-212. doi: 10.1016/j.tibtech.2011.01.008

Wang, Y., Qi, Y., Chen, C., Zhao, C., Ma, Y., and Yang, W. (2019). Layered co-immobilization of beta-glucosidase and cellulase on polymer film by visible-light-induced graft polymerization. ACS Appl. Mater. Interfaces 11, 44913-44921. doi: 10.1021/acsami.9b16274

Wei, Q., Xu, M., Liao, C., Wu, Q., Liu, M., Zhang, Y., et al. (2016). Printable hybrid hydrogel by dual enzymatic polymerization with superactivity. Chem. Sci. 7, 2748-2752. doi: 10.1039/C5SC02234G

Wilner, O. I., Weizmann, Y., Gill, R., Lioubashevski, O., Freeman, R., and Willner, I. (2009). Enzyme cascades activated on topologically programmed DNA scaffolds. Nat. Nanotechnol. 4, 249-254. doi: 10.1038/nnano. 2009.50

Wu, X., Ge, J., Yang, C., Hou, M., and Liu, Z. (2015). Facile synthesis of multiple enzyme-containing metal-organic frameworks in a biomoleculefriendly environment. Chem. Commun. 51, 13408-13411. doi: 10.1039/C5CC 05136C

Yaghi, O. M., Li, G., and Li, H. (1995). Selective binding and removal of guests in a microporous metal-organic framework. Nature 378, 703-706. doi: $10.1038 / 378703 \mathrm{a} 0$

Yang, J., Zhang, T., Tian, C., Zhu, Y., Zeng, Y., Men, Y., et al. (2019). Multi-enzyme systems and recombinant cells for synthesis of valuable saccharides: advances and perspectives. Biotechnol. Adv. 37:107406. doi: 10.1016/j.biotechadv.2019.06.005

Yang, Y., Zhang, R., Zhou, B., Song, J., Su, P., and Yang, Y. (2017). High activity and convenient ratio control: DNA-directed coimmobilization of multiple enzymes on multifunctionalized magnetic nanoparticles. ACS Appl. Mater. Interfaces 9, 37254-37263. doi: 10.1021/acsami.7b08553

Yu, C.-M., Yen, M.-J., and Chen, L.-C. (2010). A bioanode based on MWCNT/protein-assisted co-immobilization of glucose oxidase and 2,5dihydroxybenzaldehyde for glucose fuel cells. Biosens. Bioelectron. 25, 2515-2521. doi: 10.1016/j.bios.2010.04.016

Zhang, H., Hua, S. F., and Zhang, L. (2020). Co-immobilization of cellulase and glucose oxidase on graphene oxide by covalent bonds: a biocatalytic system for one-pot conversion of gluconic acid from carboxymethyl cellulose. J. Chem. Technol. Biotechnol. 95, 1116-1125. doi: 10.1002/jctb.6296

Zhang, J., Zhang, F., Yang, H., Huang, X., Liu, H., Zhang, J., et al. (2010). Graphene oxide as a matrix for enzyme immobilization. Langmuir 26, 6083-6085. doi: $10.1021 /$ la904014z
Zhang, L., Shi, J. F., Jiang, Z. Y., Jiang, Y. J., Qiao, S. Z., Li, J. A., et al. (2011). Bioinspired preparation of polydopamine microcapsule for multienzyme system construction. Green Chem. 13, 300-306. doi: 10.1039/C0GC00432D

Zhao, F., Li, H., Jiang, Y., Wang, X., and Mu, X. (2014). Co-immobilization of multi-enzyme on control-reduced graphene oxide by non-covalent bonds: an artificial biocatalytic system for the one-pot production of gluconic acid from starch. Green Chem. 16, 2558-2565. doi: 10.1039/c3gc42545b

Zhao, M., Li, Y., Ma, X., Xia, M., and Zhang, Y. (2019). Adsorption of cholesterol oxidase and entrapment of horseradish peroxidase in metalorganic frameworks for the colorimetric biosensing of cholesterol. Talanta 200, 293-299. doi: 10.1016/j.talanta.2019.03.060

Zhao, Y., Wang, Y., Zhang, X., Kong, R., Xia, L., and Qu, F. (2016). Cascade enzymatic catalysis in poly(acrylic acid) brushes-nanospherical silica for glucose detection. Talanta 155, 265-271. doi: 10.1016/j.talanta.2016.04.056

Zhou, Z., and Hartmann, M. (2013). Progress in enzyme immobilization in ordered mesoporous materials and related applications. Chem. Soc. Rev. 42, 3894-3912. doi: $10.1039 / \mathrm{c} 3 \operatorname{cs} 60059 \mathrm{a}$

Zhu, Y., Murali, S., Cai, W., Li, X., Suk, J. W., Potts, J. R., et al. (2010). Graphene and graphene oxide: synthesis, properties, and applications. Adv. Mater. 22, 3906-3924. doi: 10.1002/adma.201001068

Zor, C., Reeve, H. A., Quinson, J., Thompson, L. A., Lonsdale, T. H., Dillon, F., et al. (2017). $\mathrm{H}_{2}$-Driven biocatalytic hydrogenation in continuous flow using enzyme-modified carbon nanotube columns. Chem. Commun. 53, 9839-9841. doi: $10.1039 / \mathrm{C} 7 \mathrm{CC} 04465 \mathrm{H}$

Zore, O. V., Pattammattel, A., Gnanaguru, S., Kumar, C. V., and Kasi, R. M. (2015). Bienzyme-polymer-graphene oxide quaternary hybrid biocatalysts: efficient substrate channeling under chemically and thermally denaturing conditions. ACS Catal. 5, 4979-4988. doi: 10.1021/acscatal.5b00958

Conflict of Interest: The authors declare that the research was conducted in the absence of any commercial or financial relationships that could be construed as a potential conflict of interest.

Copyright (๑) $2020 \mathrm{Xu}$, Chen, Zheng and Zheng. This is an open-access article distributed under the terms of the Creative Commons Attribution License (CC BY). The use, distribution or reproduction in other forums is permitted, provided the original author(s) and the copyright owner(s) are credited and that the original publication in this journal is cited, in accordance with accepted academic practice. No use, distribution or reproduction is permitted which does not comply with these terms. 